\title{
Global fire emissions and the contribution of deforestation, savanna, forest, agricultural, and peat fires (1997-2009)
}

\author{
G. R. van der Werf ${ }^{1}$, J. T. Randerson ${ }^{2}$, L. Giglio ${ }^{3,4}$, G. J. Collatz ${ }^{4}$, M. Mu ${ }^{2}$, P. S. Kasibhatla ${ }^{5}$, D. C. Morton ${ }^{4}$, \\ R. S. DeFries ${ }^{6}$, Y. Jin ${ }^{2}$, and T. T. van Leeuwen ${ }^{1}$ \\ ${ }^{1}$ Faculty of Earth and Life Sciences, VU University, Amsterdam, The Netherlands \\ ${ }^{2}$ Department of Earth System Science, University of California, Irvine, California, USA \\ ${ }^{3}$ Department of Geography, University of Maryland, College Park, Maryland, USA \\ ${ }^{4}$ NASA Goddard Space Flight Center, Greenbelt, Maryland, USA \\ ${ }^{5}$ Nicholas School of the Environmental, Duke University, Durham, North Carolina, USA \\ ${ }^{6}$ Department of Ecology, Evolution, and Environmental Biology, Columbia University, New York, New York, USA
}

Received: 2 June 2010 - Published in Atmos. Chem. Phys. Discuss.: 30 June 2010

Revised: 21 October 2010 - Accepted: 22 November 2010 - Published: 10 December 2010

\begin{abstract}
New burned area datasets and top-down constraints from atmospheric concentration measurements of pyrogenic gases have decreased the large uncertainty in fire emissions estimates. However, significant gaps remain in our understanding of the contribution of deforestation, savanna, forest, agricultural waste, and peat fires to total global fire emissions. Here we used a revised version of the Carnegie-Ames-Stanford-Approach (CASA) biogeochemical model and improved satellite-derived estimates of area burned, fire activity, and plant productivity to calculate fire emissions for the 1997-2009 period on a $0.5^{\circ}$ spatial resolution with a monthly time step. For November 2000 onwards, estimates were based on burned area, active fire detections, and plant productivity from the MODerate resolution Imaging Spectroradiometer (MODIS) sensor. For the partitioning we focused on the MODIS era. We used maps of burned area derived from the Tropical Rainfall Measuring Mission (TRMM) Visible and Infrared Scanner (VIRS) and Along-Track Scanning Radiometer (ATSR) active fire data prior to MODIS (1997-2000) and estimates of plant productivity derived from Advanced Very High Resolution Radiometer (AVHRR) observations during the same period. Average global fire carbon emissions according to this version 3 of the Global Fire Emissions Database (GFED3) were 2.0 $\mathrm{Pg} \mathrm{C}_{\text {year }}{ }^{-1}$ with significant interannual variability during 1997-2001 (2.8 $\mathrm{Pg} \mathrm{C}_{\text {year }}{ }^{-1}$ in 1998 and 1.6 Pg C year $^{-1}$ in 2001). Globally, emissions during 2002-2007 were rela-
\end{abstract}

Correspondence to: G. R. van der Werf (guido.van.der.werf@falw.vu.nl)

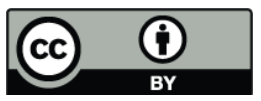

tively constant (around 2.1 $\mathrm{PgC}_{\text {year }}{ }^{-1}$ ) before declining in 2008 (1.7 $\mathrm{Pg} \mathrm{C}_{\text {year }}{ }^{-1}$ ) and 2009 (1.5 $\mathrm{Pg} \mathrm{C}_{\text {year }}{ }^{-1}$ ) partly due to lower deforestation fire emissions in South America and tropical Asia. On a regional basis, emissions were highly variable during 2002-2007 (e.g., boreal Asia, South America, and Indonesia), but these regional differences canceled out at a global level. During the MODIS era (2001-2009), most carbon emissions were from fires in grasslands and savannas (44\%) with smaller contributions from tropical deforestation and degradation fires (20\%), woodland fires (mostly confined to the tropics, $16 \%$ ), forest fires (mostly in the extratropics, $15 \%$ ), agricultural waste burning (3\%), and tropical peat fires $(3 \%)$. The contribution from agricultural waste fires was likely a lower bound because our approach for measuring burned area could not detect all of these relatively small fires. Total carbon emissions were on average 13\% lower than in our previous (GFED2) work. For reduced trace gases such as $\mathrm{CO}$ and $\mathrm{CH}_{4}$, deforestation, degradation, and peat fires were more important contributors because of higher emissions of reduced trace gases per unit carbon combusted compared to savanna fires. Carbon emissions from tropical deforestation, degradation, and peatland fires were on average $0.5 \mathrm{PgC}$ year $^{-1}$. The carbon emissions from these fires may not be balanced by regrowth following fire. Our results provide the first global assessment of the contribution of different sources to total global fire emissions for the past decade, and supply the community with an improved 13-year fire emissions time series.

(guido.van.der.werf@ falw.vu.nl)

Published by Copernicus Publications on behalf of the European Geosciences Union. 


\section{Introduction}

Over the last decade, the role of fire in shaping the environment and atmosphere has been increasingly appreciated (e.g., Langmann et al., 2009; Bowman et al., 2009). Fire is one of the most important disturbance agents in terrestrial ecosystems on a global scale and is widely used by humans to manage and transform land for many purposes, especially in tropical and subtropical ecosystems. Fires contribute significantly to the budgets of several trace gases and aerosols (Andreae and Merlet, 2001) and are one of the primary causes of interannual variability in the growth rate of several trace gases, including the greenhouse gases $\mathrm{CO}_{2}$ and $\mathrm{CH}_{4}$ (Langenfelds et al., 2002).

In many regions, pre-industrial levels of fire activity may have been comparable to or even higher than contemporary levels (Pyne, 1982; Marlon et al., 2008). In deforestation regions, however, humans are known to have increased fire activity (Fearnside, 2005; Schultz et al., 2008; Field et al., 2009). Fire activity has also increased in more remote regions due to humans (e.g., Mollicone et al., 2006). In addition, climate change may lead to more frequent and intense fires if drought conditions in areas with abundant fuel loads become more severe (Kasischke et al., 1995; Westerling et al., 2006).

To understand how fires influence and interact with the Earth system, quantitative information on emissions and a breakdown of emissions into different sources is required. This breakdown of emissions is especially important to quantify the extent to which fires contribute to the build-up of atmospheric $\mathrm{CO}_{2}$ since only deforestation fires, fires in drained peatlands, and fires from other areas that have had increasing levels of disturbance are a net source of $\mathrm{CO}_{2}$ to the atmosphere. In many other areas, $\mathrm{CO}_{2}$ emissions from fires are balanced by carbon uptake during regrowth on decadal timescales. For other trace gases and aerosols, this distinction is less important but a breakdown into categories is useful to better characterize non- $\mathrm{CO}_{2}$ anthropogenic climate forcing and to understand how human activities are affecting atmospheric chemistry. For example, all fires contribute to emissions of methane $\left(\mathrm{CH}_{4}\right)$, but the amount of $\mathrm{CH}_{4}$ released per unit biomass combusted varies greatly between different fire types. Peat fires, for example, may emit almost ten times more $\mathrm{CH}_{4}$ per unit biomass combusted than fires in savannas (Yokelson et al., 1997; Andreae and Merlet, 2001; Christian et al., 2003).

Seiler and Crutzen (1980) made the first global estimates of fire emissions, which subsequently have been refined and updated (e.g., Crutzen and Andreae, 1990; Galanter et al., 2000; Andreae and Merlet, 2001 based on unpublished data from Yevich). Hao et al. (1996) used climatological information to better understand the temporal distribution of emissions, while Schultz (2002) and Duncan et al. (2003) improved the understanding of the spatial and temporal distribution of fires, as well as their interannual variability using satellite information on fire activity (ATSR) and/or aerosol optical depths from the Total Ozone Mapping Spectrometer (TOMS). In addition to improving contemporary estimates, long-term time series during the 20th century have been constructed, primarily with the aim of understanding changes in ecosystems, the carbon cycle, and atmospheric chemistry (Mouillot et al., 2006; Schultz et al., 2008; Mieville et al., 2010).

The early approaches to estimate global fire emissions (Seiler and Crutzen, 1980; Crutzen and Andreae, 1990) de facto estimated the contribution from different sources, because estimates were based on biome-averaged fuel loads and fire frequencies (in savannas and forests) and estimates of per-capita clearing rates in combination with population densities to estimate deforestation and shifting agriculture emissions. In these studies a clear distinction was made between deforestation fires where forest is removed permanently and shifting agriculture where the clearing of forest is followed by a few years of production, after which the forest is allowed to regrow. If we exclude fuelwood burning (which is not assessed in this study) then emissions estimates from Seiler and Crutzen (1980) were 2.6 $\mathrm{Pg} \mathrm{C}_{\text {year }}{ }^{-1}$ (range of 1.7-3.5), with agricultural waste burning estimated to be the largest source of fire carbon emissions (33\%), followed by shifting agriculture (29\%), savanna $(21 \%)$, deforestation (12\%), fires in temperate areas (4\%) and fires in boreal areas (1\%). For the tropics, Crutzen and Andreae (1990) later revised the emissions estimates for deforestation and savanna fires upwards, with savanna burning becoming the main source of emissions.

More recently, global satellite-derived burned area information has become available (Grégoire et al., 2003; Simon et al, 2004; Giglio et al., 2006). These datasets have been used in combination with biogeochemical or dedicated fuel load models to estimate emissions (Hoelzemann et al., 2004; Ito and Penner, 2004; van der Werf et al., 2006; Jain et al., 2006). These studies point towards fire carbon emissions between 1 and $3 \mathrm{PgC}$ year $^{-1}$ (excluding biomass burned for domestic purposes such as cooking) with considerable uncertainty and large interannual variability (Randerson et al., 2005). The partitioning between different sources drew less attention in these new global studies because it did not lie at the core of the calculations, although the very different fuel consumption estimates for different sources were accounted for. Other studies have focused more on a particular sector; Yevich and Logan (2003), for example, calculated emissions from the burning of biofuels and agricultural waste and suggested that the latter source was substantially smaller $\left(\sim 0.2 \mathrm{Pg} \mathrm{C}_{\text {year }}{ }^{-1}\right)$ than in earlier estimates.

Besides improvements in quantifying global fire emissions, our understanding of the multifaceted role of fire in the Earth system is improving from studies quantifying the different ways fires influence climate. Randerson et al. (2006), for example, showed that the impact of (increasing) boreal forest fires on climate warming may be limited or even result 
in regional cooling because of the negative forcing from increased surface albedo following a fire. In the tropics, aerosol emissions from fires have been shown to influence the radiation budget at regional scales (Duncan et al., 2003). Climate modeling studies suggest these aerosols may lengthen or intensify periods of drought in the Amazon (Zhang et al., 2008) and in Indonesia (Tosca et al., 2010). At a global scale, changing levels of fire emissions influence 8 out of the 13 radiative forcing terms identified in the IPCC 4th Assessment (Bowman et al., 2009).

Improvements in emissions estimates are also necessary to calibrate and/or validate prognostic fire modules in dynamic global vegetation models and climate-carbon models for the period they overlap with satellite observations to make better predictions about future fire activity (e.g., Thonicke et al., 2001; Arora and Boer, 2005; Kloster et al., 2010). These models can also take advantage of a better understanding of the drivers of fires based on new satellite information. Archibald et al. (2009), for example, showed that tree cover density, rainfall over the last 2 years, and rainfall seasonality explained more than half of the variability in burned area in southern Africa. In addition, interannual variability in precipitation rates controls part of the variability in fire-driven deforestation rates from year to year, with strongest relations in Equatorial Asia where annual variability in precipitation is highest (Le Page et al., 2008; van der Werf et al., 2008).

Recently, several burned area datasets have been developed at $500 \mathrm{~m}$ or $1 \mathrm{~km}$ resolution (Roy et al., 2008; Plummer et al., 2006; Tansey et al., 2007; Giglio et al., 2009). Comparisons with Landsat-based burned area have reduced uncertainties, but large differences persist between the different approaches (Roy et al., 2009; Giglio et al. 2010). Ideally, these moderate resolution burned area datasets would be combined with fuel-load modeling at the same resolution to improve estimates of emissions. This would provide an added benefit from the perspective of validating fuel loads and fuel consumption with ground measurements. However, with the exception of Ito and Penner (2004), who built a dedicated 1-km fuel model, most global modeling frameworks are based on global biogeochemical models that were developed at coarser spatial resolutions because of conceptual and data constraints. Many of these models, for example, also are used to estimate the net carbon balance of terrestrial ecosystems. This requires additional model complexity, including tracking the flow of carbon through multi-decadal vegetation, litter, and soil carbon pools, representing the age dynamics of different forest types, and capturing climate change effects on primary production and ecosystem respiration. On regional scales, fire-dedicated research has employed native resolution satellite data; see for example Hely et al. (2007) for savanna regions in southern Africa. Working also at moderate resolution $(1 \mathrm{~km})$, Wiedinmyer et al. (2006) combined data on fire activity, land cover, and literature-derived fuel load and combustion completeness to estimate emissions for North America, while more recently Chang and Song (2010) combined MODIS burned area with fuel statistics and combustion completeness based on the Normalized Difference Vegetation Index (NDVI) to estimate emissions for tropical Asia at 500 meter resolution. For the global scale, however, combining native resolution burned area and a coarser resolution biogeochemical model for fuels may provide a useful interim solution until these biogeochemical models can run at the native resolution of the satellite data. As an example, Lehsten et al. (2009) used $1 \mathrm{~km}$ burned area to drive a $1^{\circ} \mathrm{dy}-$ namic vegetation model with 100 subgrid elements in Africa to account for stochastic processes.

Here we used new burned area estimates and an improved biogeochemical model at $0.5^{\circ}$ spatial resolution and a monthly time step to investigate global patterns of fire emissions. Our main objectives were to quantify temporal and spatial variability of fires during 1997-2009 and to assess the relative contributions of deforestation, savanna, forest, agricultural, and peat fires to fire emissions during the MODIS era. We used MODIS data on burned area and active fires (Giglio et al., 2010), land cover characteristics (Friedl et al., 2002; Hansen et al., 2003), and plant productivity (Myneni et al., 2002) to study fires over the November 2000-2009 period. Information from other sensors (TRMM-VIRS and ATSR) for burned area (Giglio et al., 2010), and AVHRR for plant productivity (Tucker et al., 2005) was used to extend our estimates back in time starting in 1997.

\section{Methods and datasets}

\subsection{Introduction}

The work presented here builds on our earlier work in which we combined information on fire activity (Giglio et al., 2003, 2006) with global biogeochemical modeling (van der Werf et al., 2003; Randerson et al., 2005; van der Werf et al., 2006). We publicly released the resulting fire emissions time series that was named the Global Fire Emissions Database version 2 (GFED2). We refer to the improved emissions time series described here as GFED version 3 (GFED3). The model we used was originally derived from the satellitedriven Carnegie Ames Stanford Approach (CASA) model (Potter et al., 1993; Field et al., 1995; Randerson et al., 1996). In this methods and datasets section we start with a brief overview of the model structure including minor modifications (Sect. 2.2), describe the major input datasets used to drive the model (Sect. 2.3), explain the major changes we made to the model (Sect. 2.4), and conclude with a description of our approach for assessing uncertainties (Sect. 2.5).

\subsection{Modeling overview}

CASA calculates carbon "pools" for each grid cell and time step based on carbon input from net primary productivity (NPP) and carbon emissions through heterotrophic respiration $\left(\mathrm{R}_{h}\right)$, fires, herbivory, and fuelwood collection. The 


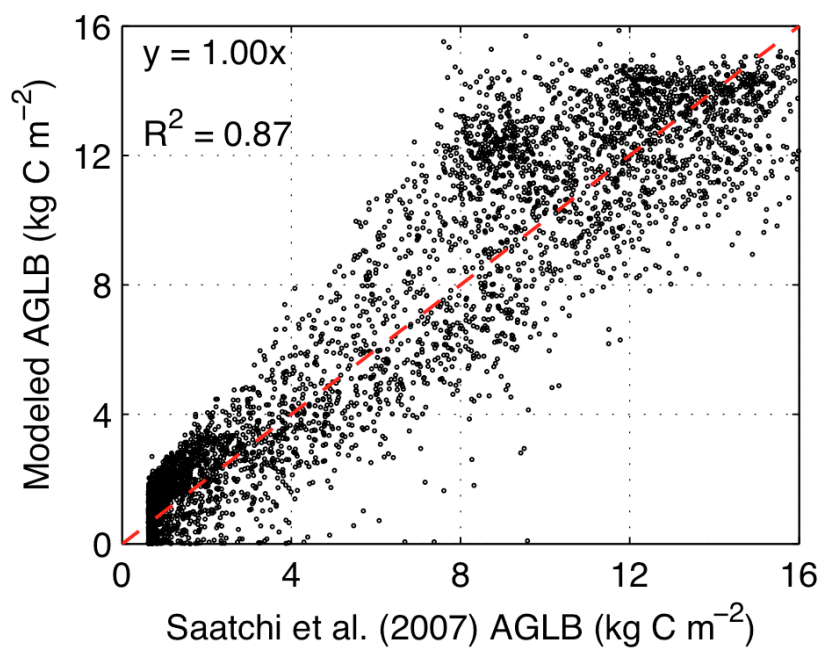

Fig. 1. Comparison of CASA predicted aboveground live biomass (AGLB; leaves and stems) with estimates from Saatchi et al. (2007) based on plot measurements and remote sensing metrics for the Amazon Basin. The red dashed line indicates a 1:1 slope. The regression was forced through the origin.

CASA version used here had a $0.5^{\circ} \times 0.5^{\circ}$ grid and a monthly time step. NPP was calculated based on satellite-derived estimates of the fraction of available photosynthetically active radiation ( $f$ APAR) absorbed by plants:

$\mathrm{NPP}=f \mathrm{APAR} \times \mathrm{PAR} \times \varepsilon_{(T, \mathrm{P})}$

where PAR is photosynthetically active radiation, and $\varepsilon$ is the maximum light use efficiency (LUE) that is downscaled when temperature $(T)$ or moisture $(\mathrm{P})$ conditions are not optimal. NPP was delivered to living biomass pools (leaves and roots for herbaceous vegetation, and leaves, roots, and stems for woody vegetation) following the Hui and Jackson (2005) allocation scheme with more NPP delivered to leaves and stems when mean annual precipitation (MAP) was high and larger amounts of NPP delivered to roots when MAP was low (ter Steege et al., 2006). By introducing this partitioning scheme we captured $87 \%$ of the variability in biomass density in the Amazon (Fig. 1), based on a biomass density assessment combining forest inventory plots with satellite data (Saatchi et al., 2007). Since the main NPP drivers ( $f$ APAR and incoming solar radiation at the surface) were relatively uniform over the Amazon and other tropical forest areas, the original partitioning based on fixed fractions of NPP would yield little spatial variability in biomass density estimates.

Carbon in the living biomass pools was transferred to litter pools depending on turnover rates and satellite-derived changes in $f$ APAR (Randerson et al., 1996) and subsequently decomposed based on turnover times regulated by temperature and soil moisture conditions (Potter et al., 1993). Other loss pathways include herbivory based on empiric relations between NPP and herbivore consumption (Mc-
Table 1. Minimum and maximum combustion completeness (CC, unitless) or maximum burn depth for different fuel types $(\mathrm{cm})$.

\begin{tabular}{llll}
\hline Fuel type & $\mathrm{CC}_{\min }$ & $\mathrm{CC}_{\max }$ & $\begin{array}{l}\text { Max. burn } \\
\text { depth }(\mathrm{cm})\end{array}$ \\
\hline Leaves & 0.8 & 1.0 & - \\
Stems & 0.2 & 0.4 & - \\
Fine leaf litter & 0.9 & 1.0 & - \\
Coarse woody debris & 0.4 & 0.6 & - \\
Boreal organic soils & - & - & 15 \\
Tropical peat organic soils & - & - & 50 \\
\hline
\end{tabular}

Naughton et al., 1989) and fuelwood collection based on national fuelwood use statistics and population densities (following van der Werf et al., 2003; see Fig. S1). Although fuelwood collection and combustion is calculated internally, we do not further discuss or present these emissions because more comprehensive analyses are available (e.g., Yevich and Logan, 2003); the module is included to more realistically simulate spatial variability in fuel availability for other types of fires.

For each grid cell and month, fire carbon emissions were then based on burned area, tree mortality, and the fraction of each carbon pool combusted (combustion completeness, $\mathrm{CC})$. Each carbon pool was assigned a unique minimum and maximum $\mathrm{CC}$ value with the fine fuels (leaves, fine litter) having relatively high values while coarse fuels (stems, coarse woody debris) having lower values (Table 1). The actual combustion completeness was then scaled linearly based on soil moisture conditions with $\mathrm{CC}$ closer to the minimum value under relatively moist conditions, and vice versa (see van der Werf et al., 2006 for more details). Burned area and tree mortality will be discussed further below.

\subsection{Main driver datasets}

Key datasets for our model were burned area, active fires, and $f$ APAR, which are described below. Additional datasets used to drive the model are summarized in Table 2, and the main changes we made to the model are summarized in Table 3 .

\subsubsection{Burned area and active fires}

We used the Giglio et al. (2010) burned area time series that is based on four satellite data sets. At the core lies a $500 \mathrm{~m}$ burned area mapping algorithm based on a burnsensitive vegetation index, with dynamic thresholds aided by active fires applied to MODIS imagery (Giglio et al., 2009). Over $90 \%$ of the area burned over 2001-2009 was mapped this way. This represented a major advance from earlier work (Giglio et al., 2006) in which less than $10 \%$ of the burned area was mapped directly. Local and regional scale relationships between MODIS active fires and burned area 
Table 2. Data sets used to drive the CASA-GFED modeling framework.

\begin{tabular}{|c|c|c|c|c|c|}
\hline Variable & Role in CASA & Data product name & Source & $\begin{array}{l}\text { Product } \\
\text { resolution }\end{array}$ & Reference \\
\hline Precipitation & $\begin{array}{l}\text { Soil moisture, impact- } \\
\text { ing NPP, } R h \text {, combus- } \\
\text { tion completeness }\end{array}$ & $\begin{array}{l}\text { Global Precipitation Clima- } \\
\text { tology Project (GPCP) ver- } \\
\text { sion } 1.1\end{array}$ & $\begin{array}{l}\text { Multi-satellite } \\
\text { and rain gauges }\end{array}$ & $1^{\circ} \times 1^{\circ}$ & $\begin{array}{l}\text { Huffmann } \\
\text { et al. }(2001)\end{array}$ \\
\hline \multirow[t]{2}{*}{ Temperature } & $\begin{array}{l}\text { Soil moisture, impact- } \\
\text { ing NPP and R } h\end{array}$ & Climatology: IIASA & Station data & $0.5^{\circ} \times 0.5^{\circ}$ & $\begin{array}{l}\text { Leemans } \\
\text { and Cramer } \\
(2001)\end{array}$ \\
\hline & & IAV: GISTEMP & Station data & $2^{\circ} \times 2^{\circ}$ & $\begin{array}{l}\text { Hansen } \\
\text { et al. (1999) }\end{array}$ \\
\hline \multirow[t]{2}{*}{$f$ APAR } & NPP calculation & 2000-2009: MOD15 & MODIS & $1 \times 1 \mathrm{~km}$ & $\begin{array}{l}\text { Myneni } \\
\text { et al. (2002) }\end{array}$ \\
\hline & & $\begin{array}{l}\text { 1997-1999: GIMMSg } \\
\text { anomalies with MODIS } \\
\text { climatology }\end{array}$ & AVHRR & $8 \times 8 \mathrm{~km}$ & $\begin{array}{l}\text { Tucker } \\
\text { et al. (2005) }\end{array}$ \\
\hline Solar radiation & NPP & GISS, ISCCP-FD & & $280 \mathrm{~km}$ & $\begin{array}{l}\text { Zhang } \\
\text { et al. (2004) }\end{array}$ \\
\hline $\begin{array}{l}\text { Vegetation continuous } \\
\text { fields }\end{array}$ & $\begin{array}{l}\text { NPP allocation, mor- } \\
\text { tality, partitioning of } \\
\text { burned area }\end{array}$ & MOD44 & MODIS & $500 \times 500 \mathrm{~m}$ & $\begin{array}{l}\text { Hansen } \\
\text { et al. (2003) }\end{array}$ \\
\hline Land cover classification & $\begin{array}{l}\text { Partitioning of burned } \\
\text { area }\end{array}$ & $\begin{array}{l}\text { MOD12 with UMD } \\
\text { classification }\end{array}$ & MODIS & $500 \times 500 \mathrm{~m}$ & $\begin{array}{l}\text { Friedl } \\
\text { et al. (2002) }\end{array}$ \\
\hline Ecoregion classification & $\begin{array}{l}\text { Classifying humid } \\
\text { tropical forest biome } \\
\text { and peatlands in } \\
\text { Southeast Asia }\end{array}$ & Ecoregions of the World & $\begin{array}{l}\text { Synthesis of } \\
\text { existing maps }\end{array}$ & Vector data & $\begin{array}{l}\text { Olson } \\
\text { et al. (2002) }\end{array}$ \\
\hline Burned area & Emissions calculation & GFED3 burned area & MODIS & $0.5^{\circ} \times 0.5^{\circ}$ & $\begin{array}{l}\text { Giglio } \\
\text { et al. (2010) }\end{array}$ \\
\hline $\begin{array}{l}\text { Burned area derived from } \\
\text { fire hot spots }\end{array}$ & $\begin{array}{l}\text { Emissions calculation } \\
\text { when MODIS } 500 \mathrm{~m} \\
\text { maps were } \\
\text { unavailable }\end{array}$ & GFED3 burned area & $\begin{array}{l}\text { MODIS, VIRS, } \\
\text { ATSR }\end{array}$ & $0.5^{\circ} \times 0.5^{\circ}$ & $\begin{array}{l}\text { Giglio } \\
\text { et al. (2010) }\end{array}$ \\
\hline $\begin{array}{l}\text { Fire hot spots ( } 2001- \\
2009 \text { climatology used } \\
\text { pre-2001) }\end{array}$ & Deforestation rates & MOD14 & MODIS & $1 \times 1 \mathrm{~km}$ & $\begin{array}{l}\text { Giglio } \\
\text { et al. (2003) }\end{array}$ \\
\hline
\end{tabular}

were used to map remaining areas in the MODIS era, while a mix of VIRS (Giglio et al., 2003) and ATSR (Arino et al., 1999) active fire data were used to map pre-MODIS burned area in a similar way. Several corrections were made to arrive at a consistent, long-term burned area dataset, see Giglio et al. (2010) for more details. This new burned area data set compared well to independent burned area estimates for North America, as well as to subsets of burned area derived from Landsat in tropical regions.

The burned area dataset includes an uncertainty assessment as well as information on the partitioning of burned area over different land cover classes and fractional tree cover bins within the $0.5^{\circ}$ grid cell. For this, the MOD12Q1 land cover map for 2001 (Friedl et al., 2002) at $1 \mathrm{~km}$ resolution in combination with the University of Maryland (UMD) land cover classification scheme, and the MOD44 vegetation continuous fields (VCF; fraction tree, herbaceous, and bare cover; Hansen et al., 2003) for 2004 was used. The distribution of burned area over land cover and fraction tree cover (FTC) is shown in Fig. 2. In addition, the fraction of burned area that occurred on tropical peatlands in Indonesia and Malaysian Borneo was obtained using the Terrestrial Ecoregions of the World map (Olson et al., 2001; http://www. worldwildlife.org/science/data/item1875.html) resampled on 
Table 3. Improvements in biogeochemical modeling framework for GFED3.

\begin{tabular}{|c|c|c|}
\hline Parameter & Description of modification & Impact on model estimates \\
\hline Burned area & $\begin{array}{l}\text { We now primarily use } 500 \mathrm{~m} \text { burned } \\
\text { area maps from MODIS during 2001- } \\
2009 \text { instead of regional relationships } \\
\text { between fire hot spots and burned area }\end{array}$ & $\begin{array}{l}\text { Estimates of burned area significantly improved } \\
\text { in North America (Giglio et al., 2010); fire emis- } \\
\text { sions estimates are no longer impacted by re- } \\
\text { gional variations in fire hot spot to burned area } \\
\text { relationships }\end{array}$ \\
\hline Spatial resolution & Increased from $1^{\circ}$ to $0.5^{\circ}$ & $\begin{array}{l}\text { Factor of } 4 \text { increase in spatial resolution; smaller } \\
\text { errors due to heterogeneity in landscape }\end{array}$ \\
\hline Leaf senescence & $\begin{array}{l}\text { Reduced carry-over of leaves during } \\
\text { the dry season to the following wet sea- } \\
\text { son in herbaceous vegetation }\end{array}$ & $\begin{array}{l}\text { Decreased biomass in herbaceous fuels, more in } \\
\text { line with measurements (e.g., Savadogo et al. } \\
\text { 2007; Williams et al., 1998) }\end{array}$ \\
\hline NPP allocation & $\begin{array}{l}\text { Changed from a fixed to a dynamic al- } \\
\text { location based on mean annual precip- } \\
\text { itation (Hui and Jackson, 2006) }\end{array}$ & $\begin{array}{l}\text { Better representation of spatial variability } \\
\text { in aboveground biomass in highly produc- } \\
\text { tive ecosystems as compared with Saatchi et } \\
\text { al. (2007) }\end{array}$ \\
\hline $\begin{array}{l}\text { Sub-grid cell information on burned } \\
\text { area distribution over land cover and } \\
\text { fractional tree cover bins }\end{array}$ & $\begin{array}{l}\text { Changed from uniform distribution of } \\
\text { burned area to herbaceous and woody } \\
\text { fuel classes to dynamic distribution } \\
\text { based on sub-grid cell information }\end{array}$ & $\begin{array}{l}\text { Improved representation of spatial and tempo- } \\
\text { ral variability in fuel type burning and mortality } \\
\text { rates; better ability to apply emission factors }\end{array}$ \\
\hline Deforestation rates & $\begin{array}{l}\text { Previous calculation based solely on } \\
\text { burned area changed to combine } \\
\text { burned area in wooded ecosystems and } \\
\text { fire hot spot persistence (Morton et al., } \\
\text { 2008; Roy et al. 2008) }\end{array}$ & $\begin{array}{l}\text { Ability to separately estimate deforestation emis- } \\
\text { sions; fuel loads in deforestation regions are no } \\
\text { longer impacted by other fire activity in the grid } \\
\text { cell (e.g., agricultural maintenance fires) }\end{array}$ \\
\hline Deforestation emissions & $\begin{array}{l}\text { Newly introduced; deforestation emis- } \\
\text { sions based on clearing rates in the } \\
\text { wooded fraction of the grid cell }\end{array}$ & $\begin{array}{l}\text { New insights into deforestation fire activity; abil- } \\
\text { ity to track deforested land through time to cal- } \\
\text { culate emissions from respiration (forthcoming } \\
\text { work) }\end{array}$ \\
\hline Uncertainty & Assessment of uncertainties & $\begin{array}{l}\text { Monte Carlo approach provided insight about the } \\
\text { spatial and temporal variability of uncertainties } \\
\text { in global fire emissions. }\end{array}$ \\
\hline
\end{tabular}

a $500 \mathrm{~m}$ resolution grid. To partition sub grid scale burned area over the various land cover types for the pre-MODIS era and when the $500 \mathrm{~m}$ burned area maps were not available, we used a monthly climatology based on burned area partitioning during the MODIS era instead of information derived from active fires in the pre-MODIS era. This was done to avoid inconsistencies among different active fire and burned area products and does not impact total burned area, only the partitioning. For example, the ATSR nighttime detection will give a smaller weight to those fires exhibiting a more pronounced diurnal cycle compared to MODIS.

\subsection{2 f APAR}

Our approach to estimating $f$ APAR for the full study period was to take advantage of the sophisticated MODIS radiative transfer algorithms for calculating $f$ APAR (Myneni et al.,
2002) and the longer time series of NDVI observations from AVHRR (Tucker et al., 2005). For 2000 onwards, we obtained MOD15 data from collection 5 at $4 \mathrm{~km}$ monthly resolution, including quality assurance meta data (QA) from the Boston University web site (http://cliveg.bu.edu/modismisr/ index.html). The $4 \mathrm{~km}$ monthly product was produced by averaging the $1 \mathrm{~km}$ monthly product. The monthly $1 \mathrm{~km}$ pixels values were derived from the 8 day $1 \mathrm{~km}$ MODIS $f$ AFPAR (native resolution). The QA for the $4 \mathrm{~km}$ product was calculated as the fraction of monthly $1 \mathrm{~km}$ pixels that were judged high quality relative the total number of pixels within a $4 \mathrm{~km}$ pixel (16). The QA for each $1 \mathrm{~km}$ monthly pixel was specified as high quality if at least one of the 4 eight-day pixels used the main algorithm. If none of the 4 inputs were from the main algorithm then the value of $f$ APAR for that month was set to the maximum value and the QA to low quality. We only used $4 \mathrm{~km}$ pixels with greater than or equal to $75 \%$ high 


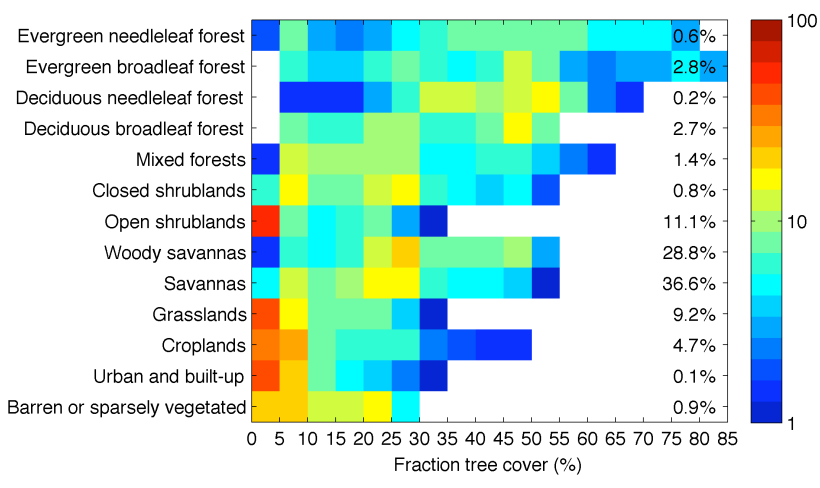

Fig. 2. Percent of burned area within each land cover class (MOD12Q1, UMD land cover classification) as a function of fractional tree cover (MOD44, 5\% bins). Numbers on the right denote the average contribution of each land cover type to global burned area over 2001-2009.

quality data (main algorithm) to calculate the mean within the $0.5^{\circ}$ grid cell.

To extend the $f$ APAR time series back to 1997 we obtained GIMMS (Global Inventory Monitoring and Modeling Study) NDVI available at biweekly $8 \mathrm{~km}$ resolution, which we aggregated to monthly, $0.5^{\circ}$ resolution. We then derived $f$ APAR for each month $(m)$ and year $(y)$ of 1997-1999 (as well as January and February 2000) and $0.5^{\circ}$ land grid cell (i) as:

$f \operatorname{APAR}_{m, y, i}=\left(\frac{d M}{d G}\right)_{i} \Delta G_{m, y, i}+M_{m, i}$

where $\left(\frac{d M}{d G}\right)_{i}$ is the slope of the linear correlation between MODIS $f$ APAR monthly anomalies and GIMMS NDVI monthly anomalies (calculated separately for each month over the 2001-2008 period of overlap), $\Delta \mathrm{G}_{m, y, i}$ is the GIMMS NDVI anomaly and $M_{m, i}$ is the mean MODIS seasonal cycle. This equation was only used in those grid cells where the $p$-value derived from the linear correlation was below 0.05 . Otherwise the climatology was used. The high correlation of the MODIS and GIMMS anomalies justified this simple approach (see Fig. S2).

\subsection{Modifications made to the modeling framework}

While the overall structure of our modeling framework did not undergo major changes, new input datasets and several smaller modifications led to substantial changes in our estimation of fire carbon emissions. We modified the model so that for the period from November 2000 onwards, it now exclusively uses MODIS data for burned area, active fire detections, vegetation productivity ( $f$ APAR), land cover classification, and fractional tree cover estimates. Data from the VIRS and ATSR sensors were used to extrapolate fire information back in time (Giglio et al., 2010).
Besides these changes to input data, two major modifications were made. First, we adjusted the burned area estimates to better account for fire-driven deforestation and used these estimates to calculate deforestation fire emissions as a separate class within each grid cell (Sects. 2.4.1, 2.4.2). Second, the sub-grid cell information on the partitioning of burned area according to land cover type and fraction tree cover bin was used to better estimate the contribution of different sources, and to partition total burned area within the $0.5^{\circ}$ grid cell into herbaceous and woody burned area. Besides deforestation fires this included savanna fires, woodland fires, forest fires, agricultural fires, and peat fires. Savanna fires were further separated into grassland and savanna fires on one hand, and woodland fires on the other (Sect. 2.4.3). These steps allowed, amongst others, for better estimates of trace gas emissions and aerosols (Sect. 2.4.5).

\subsubsection{Tropical deforestation rates}

Active fire observations may be more successful in capturing fire activity in tropical high tree cover regions than burned area datasets (Roy et al., 2008). In addition, the number of times an active fire is observed in the same grid cell (fire persistence) yields information on the fuel load and type of burning; fires in grassland and savanna areas burn rapidly with near-complete combustion of existing fuels, so if a fire is detected in a grid cell it rarely burns in the same grid cell during the consecutive overpass (Giglio et al., 2006). Deforestation fires, however, may burn over longer time periods before fuels are depleted. More fires are observed in the same location when forest is replaced with agriculture that requires nearcomplete removal of biomass than when land use following deforestation is pastureland (Morton et al., 2008). To better predict deforestation fire extent in the tropics, we therefore combined burned area and active fire detections as a proxy for the area cleared by fire in deforestation regions. We first separated burned area for the $0.5^{\circ}$ grid cell into area burned in wooded and in herbaceous cover (see Sect. 2.4.3). We then assumed that the cleared area was the product of the wooded burned area and fire persistence.

This proxy was calculated for each $0.5^{\circ}$ grid cell and for each month, with the fire persistence averaged over all $1 \mathrm{~km}$ observations within the $0.5^{\circ}$ grid cell. Specifically, the fire persistence was computed as the total number of active fire within the $0.5^{\circ}$ grid cell within a month divided by the number of $1 \mathrm{~km}$ grid cells where active fires were observed in the month. The proxy was used only in the humid tropical forest biome based on the WWF ecoregions map (Olson et al., 2001). Although empirical, it compared reasonably well to independent assessments of deforestation rates. Our approach captured about $49 \%$ of the variability in country-level deforestation rates over 2000-2005 when compared with a deforestation assessment based on the hybrid use of Landsat and MODIS data (Hansen et al., 2008). Total pan-tropical deforestation rates based on our proxy were about $82 \%$ of 


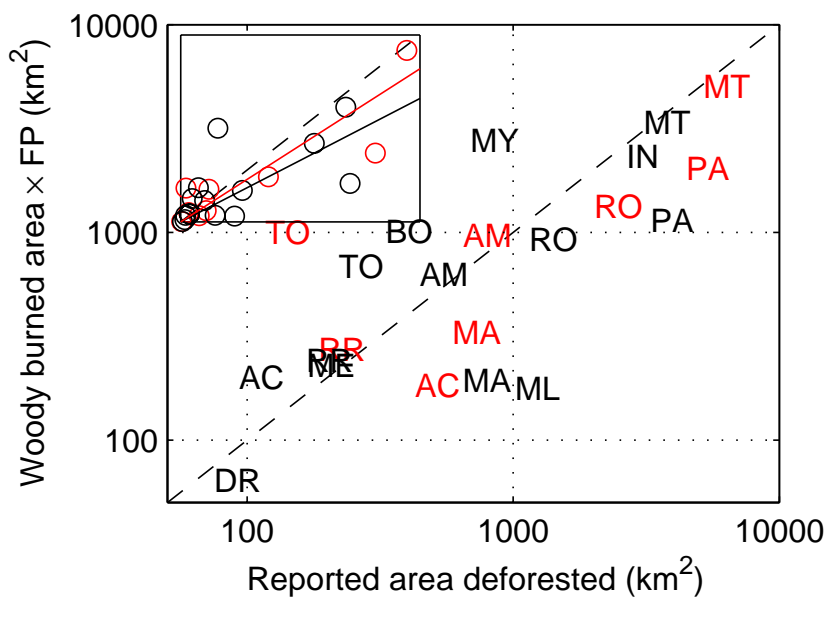

Fig. 3. Comparison of modeled deforested area with estimates from PRODES for states in the Brazilian Amazon (red, total for 2001-2006) and from Hansen et al. (2008) for tropical forest countries (black, total for 2000-2005). The dashed black line depicts the 1:1 slope. Modeled deforestation rates were based on a metric combining burned area in woody vegetation types with fire persistence (FP). Note the log scale; inset in top left shows the same data on a linear scale. The red solid line indicates the linear fit with PRODES data (slope of $0.75 ; R^{2}=0.78, n=9$ ), and black solid line shows the linear fit with Hansen et al. (2008) data (slope of $0.66 ; R^{2}=0.49 ; n=15$ ), both forced through origin. Modeled fire-driven deforestation rates were $82 \%$ of the total rates from the independent estimates. Abbreviations are DR (Democratic Republic of Congo), ME (Mexico), BO (Bolivia), MY (Myanmar), ML (Malaysia), IN (Indonesia), and the Brazilian states of AC (Acre), RR (Roraima), AM (Amazonas), RO (Rôndonia), PA (Pará), and MT (Mato Grosso).

those from Hansen et al. (2008). The state-level comparison against Landsat-derived PRODES (Programa de cálculo do desflorestamento da Amazônia) deforestation estimates for the Brazilian Amazon (http://www.obt.inpe.br/prodes/) from the Brazilian National Space Research Institute (INPE) was more favorable; we captured about $78 \%$ of the variability and again $82 \%$ of the total deforestation over the 2001-2006 period (Fig. 3). Cleared area was used to adjust the VCF fields over time; starting from the year 2004 (the base year for the VCF product) backwards in time the cleared fraction was added to the fraction tree cover and subtracted from the fraction herbaceous cover, and vice versa for 2004 onwards. This was only done for the VCF in $0.5^{\circ}$ grid cells to ensure proper partitioning of NPP to herbaceous and woody components; the 500 meter VCF maps used to partition burned area over different fractional tree cover bins remained unchanged due to the lack of annual maps or additional information that could be used to adjust the maps at native resolution.

In addition to the use of fire persistence in the deforestation rate assessment, it was also used to amplify combustion completeness and fire-induced tree mortality in deforestation zones (Fig. 4). Specifically, we set the combustion complete- ness so it ranged from its "normal" value (based on plant moisture content or soil moisture within the range defined in Table 1) to 1 , and fire-induced tree mortality from $80 \%$ to $100 \%$ based on the fire persistence with the minimum value set at a fire persistence of 1 and maximum values defined when fire persistence was 4 (the 95th percentile of cleared area weighted persistence).

\subsubsection{Tropical deforestation fire emissions}

Deforestation fire emissions were calculated based on biomass density from the wooded fraction of each grid cell and deforestation rates (Sect. 2.4.1). The fate of the deforested land was tracked using a new sub-grid cell class representing land that had been deforested. Carbon pool density in this class was based on the carbon pool density of the forested fraction, with the combusted fraction subtracted. In case the grid cell underwent multiple deforestation events over the study period, the carbon pools of the deforested part of the grid cell were based on an area-weighted average of the previously and newly deforested fractions. NPP allocation in the deforested fraction was treated the same as for herbaceous cover. $R_{h}$ in deforested grid cells usually exceeded NPP due to decomposition of remaining forest carbon pools in the grid cell, with the effect larger if the combustion completeness was low.

Combining the deforestation rates with biomass density estimates in the wooded fraction of the grid cell, we found that fuel consumption in deforestation regions was on average $12 \pm 5 \mathrm{kgC}$ per $\mathrm{m}^{2}$ burned for Southern Hemisphere South America. These estimates were near the upper bound of field measurements (Kaufmann et al., 1995; Guild et al. 1998) while those for Central America $\left(9 \pm 3 \mathrm{~kg} \mathrm{C}\right.$ per $\mathrm{m}^{2}$ burned) and Northern Hemisphere South America (10 $\pm 5 \mathrm{~kg}$ $\mathrm{C}$ per $\mathrm{m}^{2}$ burned) were closer to average measurements, although still on the high side. The difference in modeled fuel consumption between these three regions was mostly due to higher fire persistence that boosted our combustion completeness in Southern Hemisphere South America compared to other regions. In areas outside tropical America, fire persistence was lower and so were our fuel consumption estimates; about $5 \pm 3 \mathrm{~kg} \mathrm{C}$ per $\mathrm{m}^{2}$ burned for Africa and $7 \pm 4 \mathrm{~kg} \mathrm{C}$ per $\mathrm{m}^{2}$ burned for Central Asia. Only in Equatorial Asia was fuel consumption comparable to tropical America $\left(10 \pm 6 \mathrm{~kg} \mathrm{C}\right.$ per $\mathrm{m}^{2}$ burned), this was likely caused by our inability to separate increased fire persistence due to repetitive burning of aboveground material from increased fire persistence due to burning of peatlands. In other words, the high fuel consumption in Equatorial Asia may be a consequence of the co-existence of forests and peat soils, especially in deforestation areas where drainage canals expose peat soils to fire and oxidation during the deforestation process.

For the southern Amazon, our fuel consumption estimates resembled those found by a related modeling approach focusing on the state of Mato Grosso, Brazil, which highlighted 


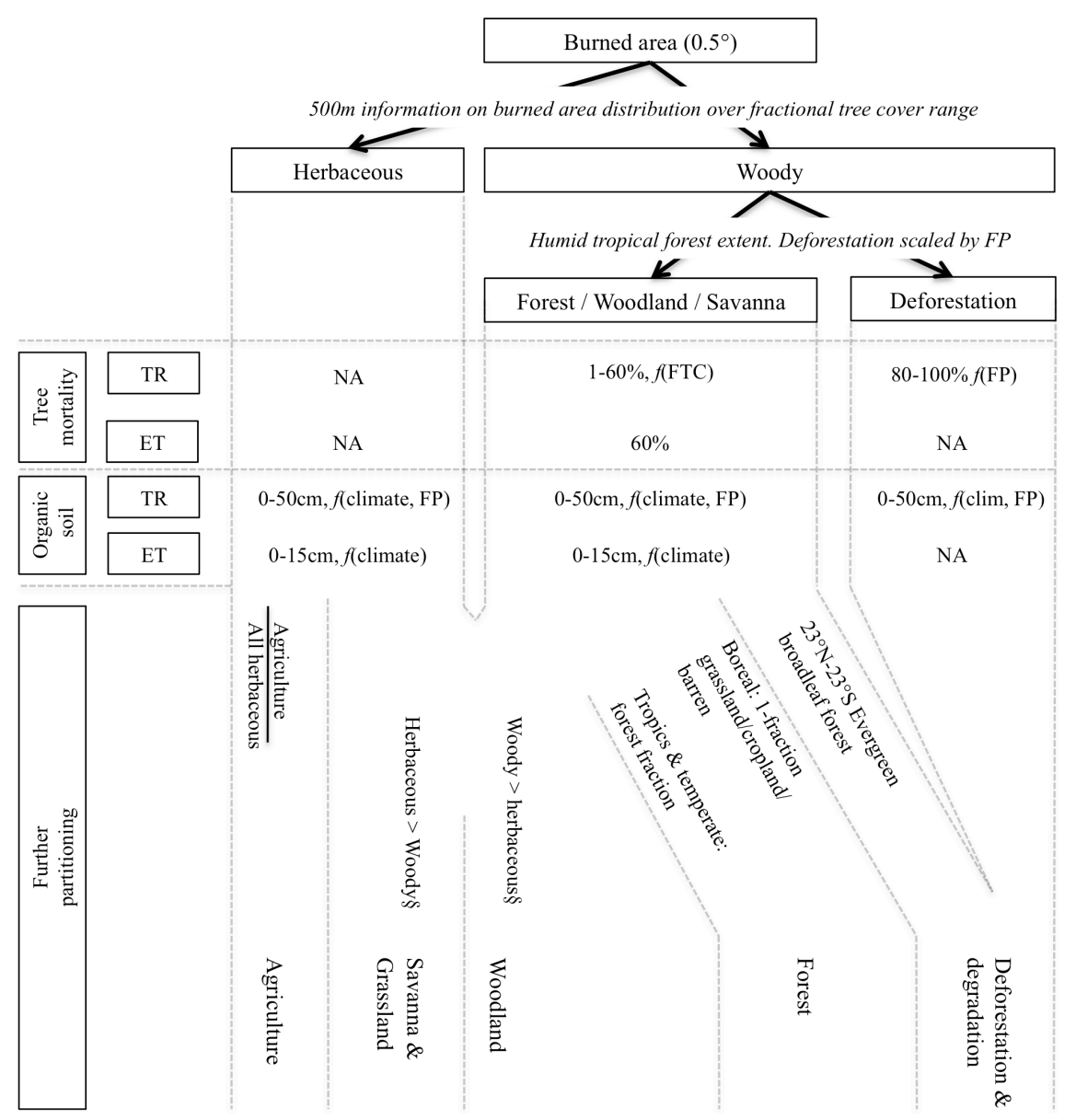

Fig. 4. Flowchart of our approach to partition burned area and emissions into different fire types. FP is fire persistence, FTC is fraction tree cover, TR tropics, and ET extratropics. The tropical "peat" class is not shown, but is based on the fraction of burned area detected in tropical peatlands and the TR scheme for estimating depth of burning into the organic soil. Since boreal fires burned in vegetation classes defined as savanna but more likely resembling open forest, the approach to estimate the forest fraction is based on excluding fires in vegetation classes without woody vegetation (Sect. 2.4.3). Note that fires in grasslands and savannas, woodlands, and forests burn both herbaceous and woody fuels, while agricultural fires burn only herbaceous fuels, and deforestation fires burn only woody fuels. Agricultural and forest fraction of emissions were subtracted before woodland and grassland and savanna burning were calculated.

the possibility of high combustion completeness and thus high fuel consumption in these areas (DeFries et al., 2008; van der Werf et al., 2009). Especially if forests are replaced with large-scale agriculture, such as for soy plantations, all aboveground biomass and even part of the belowground biomass will be combusted through repeated burns (Morton et al., 2006). Our average fuel consumption estimates for Southern Hemisphere South America were close to those calculated for conversions to soy plantations (van der Werf et al., 2009), despite 2000-2005 trends indicating higher deforestation rates for cattle ranching in Amazonia where complete combustion of forest biomass is not required. However, very large deforestation events (>500 ha) have accounted for the majority of deforested area in the Brazilian Amazon in recent years (Walker et al., 2009), indicating a trend towards mechanization of the clearing process (and higher combustion completeness) regardless of postclearing land use for pasture or soy. It is important to note that our fuel consumption estimates are annual means and may include multiple deforestation fires in the same area during a single dry season. This makes it challenging to compare our estimates with literature values, which in many instances were based on observations from a single burning event.

\subsubsection{Partitioning of non-deforestation fires}

A novel aspect of this work was to separate deforestation fires from other types of fires. In addition, we used the partitioning of $500 \mathrm{~m}$ burned area over the different land cover types within the $0.5^{\circ}$ grid to separate the non-deforestation fires in several fire types. The model tracked woody and herbaceous vegetation separately within each grid cell. Because woody fuels are an order of magnitude larger than herbaceous fuels, 
separating these two sources should provide better emissions estimates. In previous versions we applied the same amount of burned area to both fractions, with a mortality scalar based on fraction tree cover to ensure that tree mortality was low in open savanna ecosystems and increased with increasing tree cover density. Here, however, we used the partitioning of burned area maps over 5\% fraction tree cover bins (Fig. 2) to separately estimate the woody and herbaceous burned area within each $0.5^{\circ}$ grid cell (Fig. 4). The amount of burned area (BA) was distributed over tree cover bins (TC) that were each sized 5 percent points $(i)$ apart. We calculated the fraction of the total burned area occurring in the wooded part of the grid cell as:

Fraction of tree cover weighted burned area (TCWBA)

$$
=\frac{\sum_{i=1}^{i=20} \mathrm{BA}_{i} \times \mathrm{TC}_{i}}{\sum_{i=1}^{i=20} \mathrm{BA}_{i}}
$$

The resulting average fraction of burned area occurring in woody fuel types is shown in Fig. S3. For each grid cell we thus had herbaceous and woody burned area estimates that were used to drive the sub-grid cell carbon flux calculations, with the most important difference being the inclusion of wood and coarse woody debris pools. More details on changes in the carbon model are described below; here we focus on how we partitioned the emissions into different sources (Fig. 4). The simplest partitioning within our model framework was for grassland fires (herbaceous) versus forest fires (woody). However, most land cover types consist of a mixture of herbaceous and woody plant functional types, such as savannas, where trees and grasses are interspersed over the landscape. We therefore based the partitioning of non-deforestation and non-peat fires into grassland and savanna, woodland, forest, and agricultural fire emissions using the partitioning of burned area within different landcover types defined by the MODIS MOD12Q1 product (Friedl et al., 2002) with the UMD classification scheme.

To calculate agricultural waste (AGW) emissions, we multiplied the herbaceous emissions with the fraction of total herbaceous burned area occurring in agricultural areas (class 12 in the UMD land cover classification). Another class of emissions that was solely derived from either the herbaceous or woody emissions (versus the mixture) were fires in wooded areas outside the humid tropical forest domain, but still containing evergreen broadleaf forest. We confined our deforestation-clearing estimate (Sect. 2.4.1) to humid tropical forests defined in spatial extent by the WWF ecoregions map (Olson et al., 2001). Fire emissions from trees that occurred in grid cells containing evergreen broadleaf forest but outside the humid tropical forest domain were here included as degradation emissions to separate them from deforestation and degradation fires within the humid tropical forest biome, and to be able to assign them a different emission factor. However, this distinction is somewhat arbitrary; below we will refer to deforestation and degradation emissions to cover all non-savanna (so excluding grassland, savanna, and woodland fires) or agricultural fires occurring in the tropical forest domain irrespectively of whether they caused permanent land use changes (deforestation) or were, for example, escaped fires (degradation).

We next calculated the fraction of emissions associated with forest fires. In the boreal region, according to the UMD classification a large fraction of the burned area were observed in savanna-type ecosystems that more likely resembled forests with relatively low tree cover (e.g., taiga); we therefore labeled fires in shrublands and woody savannas (class 7-9) as forest fires in this region. We defined the boreal region as all land with below zero degrees Celsius mean annual temperature and more than $100 \mathrm{~mm}_{\text {year }}{ }^{-1}$ mean annual precipitation. The precipitation threshold was included so that high latitude arid grassland areas such as those found in Mongolia were treated as grassland. Boreal forests were unique in that emissions included burning in forest, shrubland, and wood savanna classes. In other regions, forest emissions were based only on burned area that occurred within the forest classes (Fig. 4).

The remainder of emissions stemmed from grasslands and savannas, with the latter ranging from open savannas to woodlands. To distinguish grassland and open savannas from woodlands, we separated these two sources based on the dominant source of emissions; if herbaceous emissions dominated then we labeled them grassland and savanna fires, otherwise woodland fires (Fig. 4).

\subsubsection{Additional changes (tree mortality, combustion completeness, leaf litterfall)}

Tree mortality $\left(M_{w}\right)$ was modeled similar to earlier model versions as a function of fractional tree cover so that savannatype ecosystems had only $1 \%$ mortality which started to increase when tree cover exceeded $30 \%$ to reach the maximum of $60 \%$ mortality in areas with more than $70 \%$ tree cover following:

$M_{w}=0.01+0.59 /\left(1+e^{(25 \times(0.50-\mathrm{TCWBA}))}\right)$

While in earlier version this mortality scalar was fixed in each grid cell based on the fraction tree cover in the grid cell, here we used sub-grid cell information to model mortality more dynamically, allowing it to change over time. Specifically, we used an estimate of tree cover weighted by burned area (TCWBA) that changed for each time step (Eq. 3). Two region-specific modifications to Eq. (4) were made; we scaled the mortality in deforestation regions to values between 80 and $100 \%$ based on fire persistence (as described in Sect. 2.4.1) and (similar to earlier modeling versions) applied a fixed mortality of $60 \%$ in forested regions in temperate and 
Table 4. 1997-2009 area-averaged fire return time, NPP, fuel consumption per unit area burned (BA), and combustion completeness for different regions.

\begin{tabular}{|c|c|c|c|c|c|c|c|c|c|c|}
\hline \multirow[t]{2}{*}{ Region $^{1}$} & \multirow{2}{*}{$\begin{array}{c}\text { Area } \\
\left(\mathrm{Mkm}^{2}\right)\end{array}$} & \multirow{2}{*}{$\begin{array}{l}\text { Fire return time } \\
\text { (Year) }\end{array}$} & \multirow{2}{*}{$\begin{array}{c}\text { NPP } \\
\left(\mathrm{gC} \mathrm{m}^{-2} \text { year }^{-1}\right)\end{array}$} & \multicolumn{4}{|c|}{ Fuel consumption $\left(\mathrm{g} \mathrm{C} \mathrm{m}^{-2}\right.$ of BA) } & \multicolumn{3}{|c|}{ Combustion completeness (-) } \\
\hline & & & & Standing & Surface & Soil & Total & Standing (burned) ${ }^{2}$ & Standing (all) ${ }^{3}$ & Surface \\
\hline BONA & 11.25 & 550 & 235 & 270 & 488 & 1904 & 2662 & 0.38 & 0.23 & 0.69 \\
\hline TENA & 7.94 & 540 & 388 & 219 & 407 & 0 & 627 & 0.40 & 0.17 & 0.75 \\
\hline CEAM & 2.71 & 197 & 674 & 682 & 803 & 4 & 1489 & 0.45 & 0.22 & 0.79 \\
\hline NHSA & 3.02 & 139 & 1001 & 455 & 551 & 2 & 1007 & 0.56 & 0.20 & 0.81 \\
\hline SHSA & 14.79 & 72 & 796 & 668 & 634 & 9 & 1311 & 0.55 & 0.29 & 0.82 \\
\hline EURO & 5.41 & 827 & 400 & 202 & 462 & 3 & 667 & 0.43 & 0.21 & 0.80 \\
\hline MIDE & 12.03 & 1363 & 35 & 30 & 169 & 0 & 198 & 0.59 & 0.16 & 0.93 \\
\hline NHAF & 14.73 & 12 & 366 & 108 & 269 & 0 & 377 & 0.60 & 0.09 & 0.86 \\
\hline SHAF & 9.92 & 8 & 627 & 108 & 340 & 0 & 448 & 0.55 & 0.07 & 0.83 \\
\hline BOAS & 15.28 & 236 & 257 & 157 & 398 & 1424 & 1979 & 0.34 & 0.21 & 0.70 \\
\hline TEAS & 18.25 & 130 & 205 & 50 & 142 & 61 & 253 & 0.40 & 0.30 & 0.84 \\
\hline CEAS & 6.63 & 94 & 545 & 800 & 650 & 8 & 1459 & 0.47 & 0.29 & 0.80 \\
\hline EQAS & 2.61 & 130 & 1213 & 2937 & 1181 & 5382 & 9500 & 0.49 & 0.47 & 0.77 \\
\hline AUST & 7.98 & 15 & 238 & 53 & 206 & 0 & 259 & 0.69 & 0.09 & 0.88 \\
\hline
\end{tabular}

${ }^{1}$ See Fig. 7 for the list of region abbreviations. ${ }^{2}$ Fraction combusted of all litter and all biomass killed by fire. ${ }^{3}$ Fraction combusted of all litter and biomass.

boreal regions (based on a mean annual temperature threshold of below $15^{\circ} \mathrm{C}$ ) where tree cover density was often far below $70 \%$. We made this modification in recognition that stand-replacing crown fires often occur in many temperate and boreal forests. A map of mean fire-induced tree mortality is shown in Fig. S4. Although in some areas of the boreal forest mortality can approach $100 \%$, particularly in areas with moderate and severe fires, we applied a $60 \%$ mortality to reflect the observation that within burn perimeters there are often many areas that are incompletely burned, or even entirely unburned.

The key fuel component in the boreal region is the soil, which is most often the major source of emissions. This is also the case for Equatorial Asia, most importantly in Indonesia (Page et al., 2002). Organic soil burning was modeled in a similar fashion as combustion completeness; we set a minimum and maximum burning depth value $(0$ and $15 \mathrm{~cm}$ for the boreal region, 0 and $50 \mathrm{~cm}$ for Equatorial Asia), which was then scaled based on soil moisture conditions (from both the current and the previous month) for the boreal region, and a combination of soil moisture conditions and fire persistence for Equatorial Asia. Specifically, we used the square root of the product of the soil dryness scalar (1 minus soil moisture) and fire persistence to describe the potential for fires to burn into the soil, a process that may not be fully captured by satellite measurements. Following an approach similar to our earlier work (van der Werf et al., 2006), we modified the turnover rates of the soil pools to mimic measured organic soil carbon stocks (see Sect. 2.4.6). For the boreal region, we assumed that only in those areas with a mean annual temperature below zero the organic soil burns, while the fraction of emissions in Indonesian peatlands was derived from the fraction of area burned observed on grid cells identified as peat (see Giglio et al., 2010). Due to the lack of spatially-explicit maps, peat and organic soil burning outside Indonesia and outside areas with below $0{ }^{\circ} \mathrm{C}$ mean annual temperature were not included.

In North America, organic soil burning had a mean depth of $8 \pm 3 \mathrm{~cm}$ during $1997-2009$ and with this parameterization our fuel consumption estimates agreed with the 0.8$3 \mathrm{~kg} \mathrm{C} \mathrm{m}^{-2}$ dominant range (and outliers to $5 \mathrm{~kg} \mathrm{C} \mathrm{m}^{-2}$ ) found in recent literature (DeGroot et al., 2007; DeGroot et al., 2009; Boby et al., 2010). Average depth of burning in Indonesia $(30 \pm 8 \mathrm{~cm})$ was similar to results from a largescale assessment of depth of burning in Borneo using LIDAR measurements (Ballhorn et al., 2009), resulting in a burning depth of $33 \pm 18 \mathrm{~cm}$.

In addition, we modified the leaf litterfall parameterization; in previous versions the amount of leaves and grasses decreased only slightly after the growing season. This led to a larger than desired build-up of leaves, and thus to an overestimation of fuel, especially in areas dominated by herbaceous fuels such as savannas. By lowering the turnover time of leaves to 6 months and modifying other parts of the algorithm, the leaf litterfall component, the leaf pool build-up and its depletion following the growing season performed better. Average fuel consumption estimates for savanna-dominated regions (Africa and Australia) were about half of those previously found (Table 4 versus Table 4 in van der Werf et al., 2006).

Measurements of Savadogo et al. (2007) in savannawoodlands in West Africa showed that grazing lowers fuel loads by up to $50 \%$ compared to areas without grazing. They also found significant differences in fuel loads between annual and perennial grasses. Although our model includes grazing based on a global relation between plant productivity and herbivory, fine-scale differences like these cannot be reproduced due to the relatively coarse spatial resolution of our model. Fuel loads between different treatments varied between 170 and $450 \mathrm{~g} \mathrm{C} \mathrm{m}^{-2}$ (Savadogo et al., 2007). In 

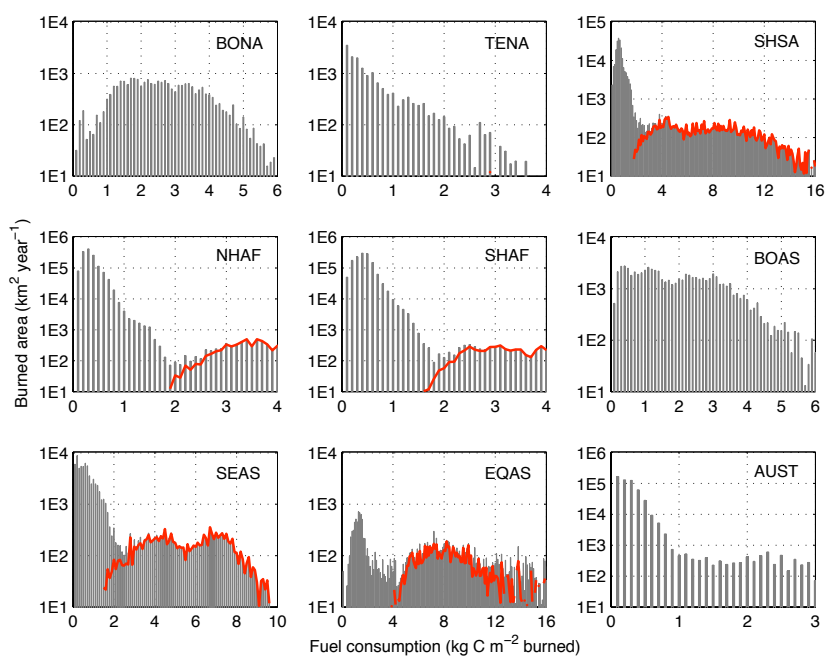

Fig. 5. Frequency distribution of fuel consumption in different regions (See Fig. 7 for the list of region abbreviations), with deforestation fires marked in red. Note the logarithmic y-axis scale and the different $\mathrm{x}$-axis scales for each plot. Each bar represents $0.1 \mathrm{kgC}$ per $\mathrm{m}^{2}$ of burned area, averaged over 1997-2009, centered upon its mean.

the $0.5^{\circ}$ grid cell encompassing their study region, modeled minimum fuel loads were $200 \mathrm{~g} \mathrm{C} \mathrm{m}^{-2}$, based on fuel build up after one year. Maximum fuel loads were $550 \mathrm{~g} \mathrm{C} \mathrm{m}^{-2}$ when fires were excluded in our model, which was somewhat larger than observed in the field. In savanna areas of northern Australia, Williams et al. (1998) performed a landscape-scale experiment where fuel loads were found to range between 75 and $650 \mathrm{~g} \mathrm{C} \mathrm{m}^{-2}$ with most fires burning in areas with 100$200 \mathrm{~g} \mathrm{C} \mathrm{m}^{-2}$ of fuel. For Australia as a whole, we found that most fires consumed less than $100 \mathrm{~g} \mathrm{C} \mathrm{m}^{-2}$ of fuel although a substantial amount of burning occurred in areas where consumption ranged between $100-400 \mathrm{~g} \mathrm{C} \mathrm{m}^{-2}$ (Figs. 5, 6). In the area where Williams et al. (1998) performed their measurements average fuel consumption was about $250 \mathrm{~g} \mathrm{C} \mathrm{m}^{-2}$ of fuel while maximum fuel consumption (reached when fires were excluded for 5 years) was $600 \mathrm{~g} \mathrm{C} \mathrm{m}^{-2}$ of fuel. While far from exhaustive, these comparisons were encouraging.

\subsubsection{Trace gas emissions}

Our modeling framework calculated carbon fluxes. Emission factors (EF) were then used to translate the fire carbon loss to trace gas and aerosol emissions. EFs have been measured in most fire-prone biomes, compiled by Andreae and Merlet (2001) and updated annually (M. O. Andreae, personal communication, 2009). We used separate EFs from this database for fires in (1) tropical forests, (2) grasslands and savannas, (3) extratropical forests, and (4) agricultural residues. The EFs were based on the mean of the measurements for each species within each of the 4 biomes described

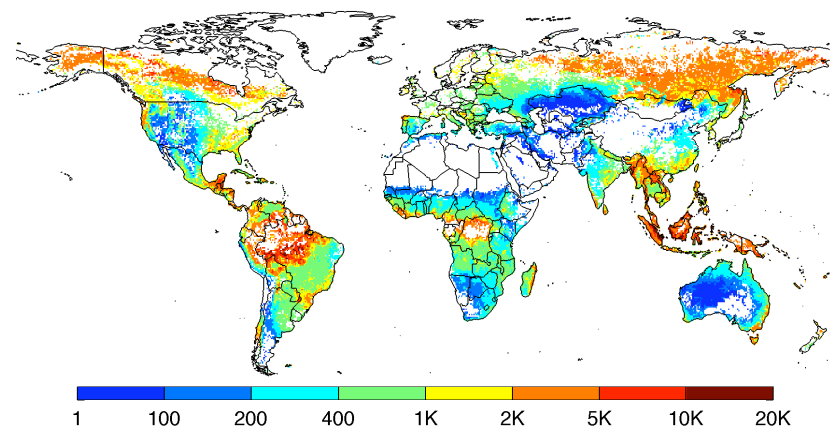

Fig. 6. Fuel consumption ( $\mathrm{g} \mathrm{C}$ per $\mathrm{m}^{2}$ of area burned), averaged over 1997-2009.

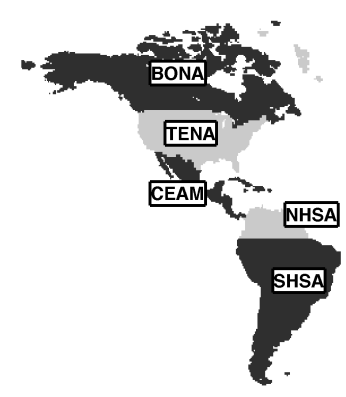

BONA Boreal North America

TENA Temperate North America CEAM Central America

NHSA Northern Hemisphere South America SHSA Southern Hemisphere South America EURO Europe MIDE Middle East

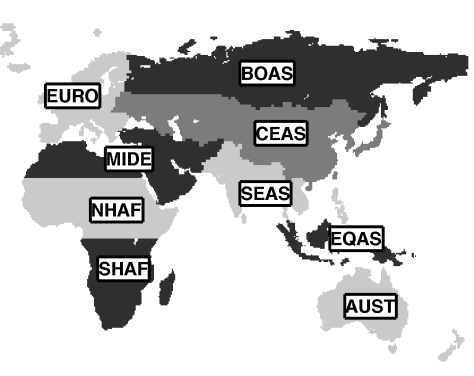

NHAF Northern Hemisphere Africa SHAF Southern Hemisphere Africa BOAS Boreal Asia CEAS Central Asia

SEAS Southeast Asia EQAS Equatorial Asia AUST Australia and New Zealand
Fig. 7. Map of the 14 regions used in this study, after Giglio et al. (2006) and van der Werf et al. (2006).

above, with EFs for tropical forest fires applied to deforestation fires. For tropical peat burning we were aware of only one study that collected soils from the field for laboratory analysis (Christian et al., 2003). EFs from this study for reduced species were about twice as high as those for tropical forest fires. Deforestation and degradation fires in the nonhumid tropics received the average EF from (1) grasslands and savannas and (2) tropical forest fires because they represent a mixture of these fire types, and we applied the same EF to woodland fires. We did not apply separate emission factors for above- and belowground fuel components in extratropical forest fires because available field measurements had a large range of variability that integrated across these two sources of emissions. EFs were reported per kilogram dry matter burned. Based on mass balance equations of the EFs $\left(\mathrm{CO}_{2}\right.$ $+\mathrm{CO}+\mathrm{CH}_{4}$ ), we used a dry matter carbon content of approximately $48 \%$ to convert model estimates of fire carbon emissions to dry matter emissions (prior to the application of EFs), with the exception of $44 \%$ for agricultural fires and $56 \%$ for peat fires. The EFs we used for several trace gas and aerosol species are given in Table 5. 
Table 5. Emission factors used for different fire types, in g specie per kg dry matter burned.

\begin{tabular}{|c|c|c|c|c|c|c|}
\hline & Deforestation $^{1}$ & $\begin{array}{l}\text { Savanna and } \\
\text { Grassland }^{1}\end{array}$ & Woodland $^{2}$ & $\begin{array}{l}\text { Extratropical } \\
\text { forest }^{1}\end{array}$ & $\begin{array}{l}\text { Agricultural } \\
\text { waste burning }\end{array}$ & Peat fires ${ }^{3}$ \\
\hline Carbon $^{4}$ & 489 & 476 & 483 & 476 & 440 & 563 \\
\hline $\mathrm{CO}_{2}$ & 1626 & 1646 & 1636 & 1572 & 1452 & 1703 \\
\hline $\mathrm{CO}^{-}$ & 101 & 61 & 81 & 106 & 94 & 210 \\
\hline $\mathrm{CH}_{4}$ & 6.6 & 2.2 & 4.4 & 4.8 & 8.8 & 20.8 \\
\hline NMHC & 7.00 & 3.41 & 5.21 & 5.69 & 11.19 & 7.00 \\
\hline $\mathrm{H}_{2}$ & 3.50 & 0.98 & 2.24 & 1.78 & 2.70 & 3.50 \\
\hline $\mathrm{NO}_{\mathrm{X}}$ & 2.26 & 2.12 & 2.19 & 3.41 & 2.29 & 2.26 \\
\hline $\mathrm{N}_{2} \mathrm{O}$ & 0.20 & 0.21 & 0.21 & 0.26 & 0.10 & 0.20 \\
\hline $\mathrm{PM}_{2.5}$ & 9.05 & 4.94 & 7.00 & 12.84 & 8.25 & 9.05 \\
\hline TPM & 11.8 & 8.5 & 10.2 & 17.6 & 12.4 & 11.8 \\
\hline $\mathrm{TC}$ & 6.00 & 3.71 & 4.86 & 8.28 & 6.19 & 6.00 \\
\hline $\mathrm{OC}$ & 4.30 & 3.21 & 3.76 & 9.14 & 3.71 & 4.30 \\
\hline $\mathrm{BC}$ & 0.57 & 0.46 & 0.52 & 0.56 & 0.48 & 0.57 \\
\hline $\mathrm{SO}_{2}$ & 0.71 & 0.37 & 0.54 & 1.00 & 0.40 & 0.71 \\
\hline
\end{tabular}

${ }^{1}$ Based on Andreae and Merlet (2001) and Andreae (M. O. Andreae, personal communication, 2009). ${ }^{2}$ Based on the average of the grassland and savanna, and deforestation emission factor. The same emission factor was applied to deforestation and degradation emissions outside the humid tropical forest biome. ${ }^{3}$ Based on Christian et al. (2003) for $\mathrm{CO}_{2}, \mathrm{CO}$, and $\mathrm{CH}_{4}$; other species based on deforestation fires. ${ }^{4}$ Dry matter carbon content based on carbon content in $\mathrm{CO}_{2}$, $\mathrm{CO}_{\text {, and }} \mathrm{CH}_{4}$ emission factors.

\subsubsection{Spin-up}

We spun up CASA for 250 years based on average input data from 1997-2009 so that carbon release $\left(R_{h}\right.$, fires, herbivory, fuelwood collection) matched input (NPP), indicating that all carbon pools were in steady state. Because of the long turnover rates of slowly decomposing soil pools, these pool sizes were tuned prior to the spin up to match measured carbon densities (Batjes et al., 1996) by adjusting the turnover times of the slow soil pools by a single scalar in each $0.5^{\circ}$ grid cells. Fire return times for forests were based on the mean fire interval for each basis region (Fig. 7) and for each $10 \%$ fraction tree cover bin to create region-specific and to some extent ecosystem-specific average fire return times (Fig. S5). This approach substituted space for time (Chuvieco et al., 2008) and was undertaken to create realistic fuel loads in areas that burned extensively during the study period but may have had infrequent fire activity in earlier periods.

\subsection{Uncertainty}

While the burned area assessment underwent a formal uncertainty assessment, a similar approach for estimating uncertainties in fuel loads, combustion completeness, and emission factors was not yet possible due to a lack of ground truth data. However, to get an initial estimate of the spatial variability in uncertainties in carbon emissions we propagated the uncertainties from the burned area estimates through our model in a set of Monte Carlo simulations. We also assigned subjective best-guess estimates of other model parameter uncertainties in these simulations (Table 6) following approaches described by French et al. (2004) and Jain et
Table 6. Reported and best-guess uncertainties $(1 \sigma)$ for various parameters influencing fire emission estimates.

\begin{tabular}{ll}
\hline Parameter & Uncertainty \\
\hline Burned area & $\begin{array}{l}\text { Reported standard deviation } \\
\text { (Giglio et al., 2010) }\end{array}$ \\
Deforested area & $\begin{array}{l}\text { Reported burned area } \\
\text { standard deviation } \times 2\end{array}$ \\
Woody biomass & $22 \% 1$ \\
Herbaceous biomass & $44 \%^{2}$ \\
Tree mortality & $25 \%$ \\
Depth of soil burning & $50 \%$ of range \\
Combustion completeness & $50 \%$ of range \\
\hline
\end{tabular}

${ }^{1}$ Based on a comparison of Amazon biomass with data from Saatchi et al. (2007). 2 Double the uncertainty of woody biomass due to more factors impacting herbaceous biomass that may not be accurately represented at low spatial resolution, such as time since last fire, grazing, etc.

al. (2007), though the latter used error propagation instead of a Monte Carlo simulation.

Specifically, we attributed best-guess uncertainties to several parameters used to calculate emissions (Table 6). Normally-distributed uncertainties for the light use efficiency (scaling directly to biomass density), burned area, combustion completeness, and burning depth into organic soil were used. We performed 2000 runs based on spin-up data from the main run and with the biomass pools adjusted with the change in LUE (which led to a linear change in biomass density), and then ran 1997-2009 and changed the other parameters independently. We focused the uncertainty analysis on 
Table 7. Annual emissions estimates (Tg C year ${ }^{-1}$ ) over 1997-2009 for different regions ${ }^{1}$.

\begin{tabular}{|c|c|c|c|c|c|c|c|c|c|c|c|c|c|c|c|}
\hline Region $^{2}$ & 1997 & 1998 & 1999 & 2000 & 2001 & 2002 & $\begin{array}{l}\text { Year } \\
2003\end{array}$ & 2004 & 2005 & 2006 & 2007 & 2008 & 2009 & Mean & $\begin{array}{r}\text { Contribution } \\
(\%)\end{array}$ \\
\hline BONA & 19 & 116 & 36 & 14 & 5 & 69 & 60 & 139 & 66 & 50 & 40 & 49 & 44 & 54 & 2.7 \\
\hline TENA & 2 & 8 & 11 & 12 & 6 & 10 & 9 & 4 & 6 & 11 & 20 & 13 & 8 & 9 & 0.5 \\
\hline CEAM & 14 & 60 & 14 & 27 & 9 & 13 & 28 & 8 & 27 & 20 & 14 & 14 & 19 & 20 & 1.0 \\
\hline NHSA & 20 & 51 & 14 & 19 & 17 & 9 & 54 & 26 & 13 & 11 & 25 & 13 & 13 & 22 & 1.1 \\
\hline SHSA & 201 & 412 & 298 & 137 & 143 & 231 & 214 & 327 & 459 & 241 & 572 & 194 & 91 & 271 & 13.4 \\
\hline EURO & 4 & 6 & 3 & 9 & 5 & 2 & 5 & 3 & 5 & 4 & 7 & 2 & 2 & 4 & 0.2 \\
\hline MIDE & 1 & 2 & 2 & 1 & 2 & 2 & 2 & 2 & 1 & 2 & 3 & 1 & 2 & 2 & 0.1 \\
\hline NHAF & 581 & 586 & 511 & 532 & 428 & 479 & 506 & 407 & 532 & 442 & 441 & 445 & 362 & 481 & 23.9 \\
\hline SHAF & 514 & 682 & 534 & 514 & 514 & 483 & 597 & 579 & 621 & 548 & 533 & 578 & 544 & 557 & 27.7 \\
\hline BOAS & 42 & 338 & 85 & 141 & 103 & 191 & 333 & 16 & 48 & 96 & 46 & 165 & 66 & 128 & 6.4 \\
\hline TEAS & 57 & 31 & 18 & 37 & 33 & 49 & 43 & 25 & 27 & 35 & 35 & 40 & 31 & 36 & 1.8 \\
\hline CEAS & 65 & 187 & 160 & 56 & 40 & 91 & 69 & 166 & 87 & 83 & 165 & 64 & 106 & 103 & 5.1 \\
\hline EQAS & 1069 & 184 & 33 & 21 & 70 & 285 & 71 & 109 & 123 & 368 & 21 & 25 & 101 & 191 & 9.5 \\
\hline AUST & 118 & 112 & 182 & 146 & 186 & 153 & 128 & 155 & 89 & 147 & 122 & 78 & 136 & 135 & 6.7 \\
\hline Global & 2705 & 2775 & 1901 & 1665 & 1561 & 2066 & 2118 & 1966 & 2105 & 2059 & 2043 & 1681 & 1524 & 2013 & 100.0 \\
\hline
\end{tabular}

1 Annual estimates for other trace gases, as well as the contribution of different fire types, can be found on http://www.globalfiredata.org/. ${ }^{2}$ See Fig. 7 for the list of region abbreviations.

carbon emissions and not all errors were included; we did not, for example, include errors in the fractional tree or land cover that were used in several places in our model.

The uncertainty we assigned to biomass was based on the comparison with Amazonian biomass (Fig. 1). Specifically, we used the square root of the mean of the squared residuals of the comparison. Since the scatter increased with biomass density (heteroskedasticity), the standard deviation was applied as a scaling factor (here the light use efficiency) instead of an absolute value. For herbaceous fuels, the same standard deviation was used but we doubled the value to account for additional uncertainties such as the amount of grazing and our inability to accurately determine the time since the previous fire (one of the key factors regulating the amount of herbaceous fuels) due to our relatively coarse resolution model set-up. Standard deviations for combustion completeness and depth of burning were estimated subjectively as half of their respective ranges. For depth of burning into organic soil in boreal regions, for example, the standard deviation was set to $7.5 \mathrm{~cm}$. These values are relatively large and should account for the substantial uncertainty here, which probably exceeds uncertainties in combustion completeness, although no formal assessment was done.

For combustion completeness, burned area, and the depth of burning into organic soil, we truncated the distributions to avoid physically unrealistic scenarios. For example, if the combustion completeness exceeded unity or the depth of burning was negative, these were cut-off at 1 and 0 , respectively. Therefore uncertainties in some areas were not necessarily normally-distributed, and the mode of the Monte Carlo runs was not necessarily the same as the values we report as our best estimates.

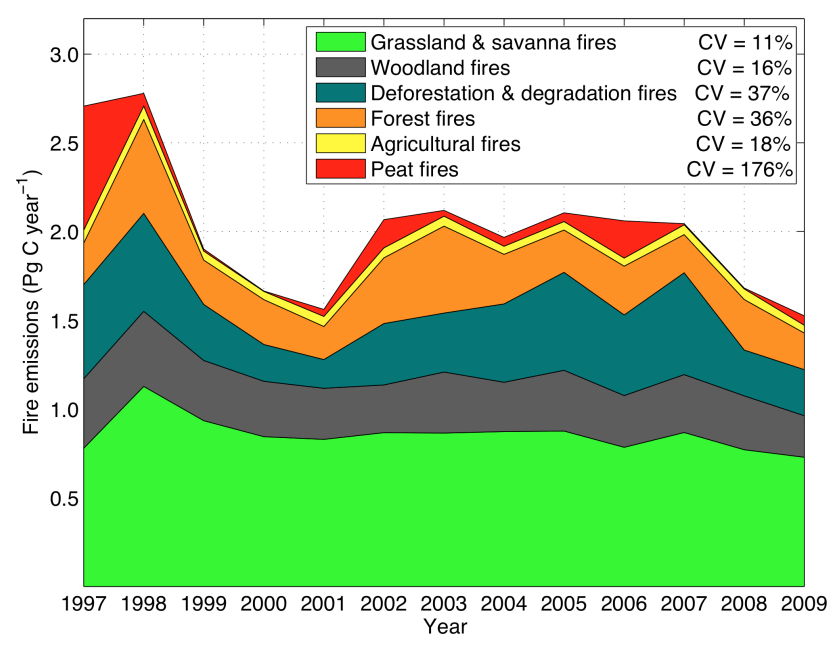

Fig. 8. Cumulative annual carbon emissions from different fire types and their coefficient of variation (CV) during 1997-2009.

\section{Results}

\subsection{Emissions}

\subsubsection{Global overview}

Average carbon emissions over 1997-2009 were 2.0 $\mathrm{PgC}$ year $^{-1}$ with considerable interannual variability, especially over the 1997-2001 period (Figs. 8, 9, Table 7). Emissions in the peak fire year $1998\left(2.8\right.$ Pg year $\left.^{-1}\right)$ were $78 \%$ higher than those in $2001\left(1.6\right.$ Pg year $\left.^{-1}\right)$. From 2002 through 2007, emissions were relatively constant from year to year on a global scale. Regionally, however, large 

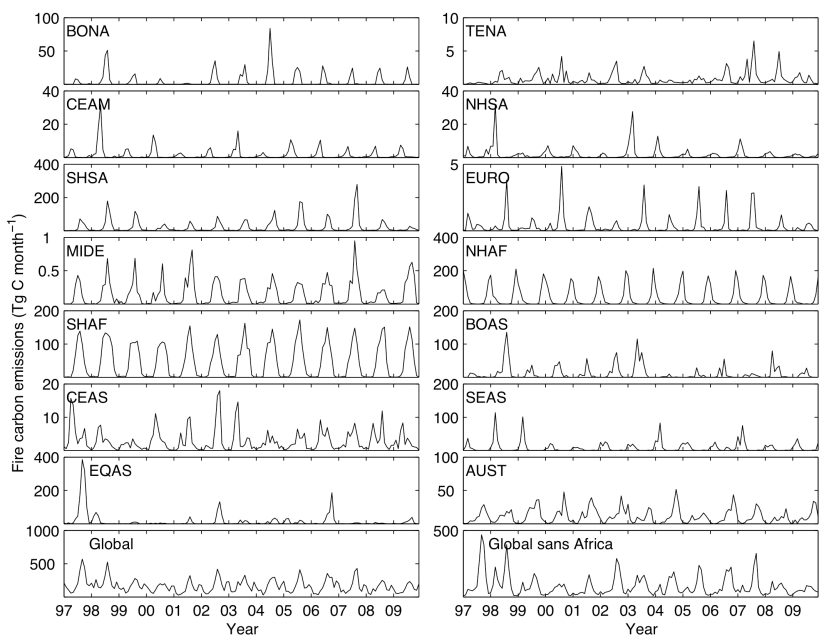

Fig. 9. Monthly fire emissions estimates $\left(\mathrm{Tg} \mathrm{C}\right.$ month $^{-1}$ ) over 1997-2009 for different regions (Fig. 7), as well as the global total with and without African emissions (bottom). Note the different $\mathrm{y}$-axis scales for each plot.

variations occurred but high fire years in some regions cancelled low fire years in other regions. In 2006 for example, emissions in Southern Hemisphere South America were relatively low while in Equatorial Asia emissions were higher than in any other year except 1997. In 2007 the reverse occurred with high emissions in Southern Hemisphere South America and low emissions in Equatorial Asia. In 2008, almost all regions experienced below average emissions, with the notable exception of boreal Asia, leading to a relatively low fire year globally $\left(1.7 \mathrm{Pg}_{\mathrm{year}}{ }^{-1}\right)$. This situation persisted in 2009, although boreal Asia was now also low and even though emissions in Equatorial Asia increased somewhat, 2009 was the year with lowest emission over our study period (1.5 $\left.\mathrm{Pg}_{\text {year }}{ }^{-1}\right)$.

Over half of the global carbon emissions were from Africa (Table 7), with emissions from Africa south of the equator $(28 \%)$ somewhat exceeding those from Horthern Hemisphere Africa (24\%). South America accounted for $15 \%$ of global carbon emissions, mostly from Southern Hemisphere South America. On average, Equatorial Asia was the fourth most important region (10\%) with its relative contribution growing considerably during El Niño years. In 1997, for example, we estimated that emissions from Equatorial Asia contributed to $40 \%$ of global emissions. According to our estimates, the boreal region accounted for $9 \%$ of total global carbon emissions with emissions from boreal Asia almost 2.5 times as high as those from boreal North America and comparable to emissions from Australia. While the Scandinavian countries and Finland were not included in the boreal region in our assessment, emissions here were negligible compared to boreal North America and Asia.

When translating our estimated carbon emissions to emissions of trace gases (Andreae and Merlet, 2001; M. O. An-

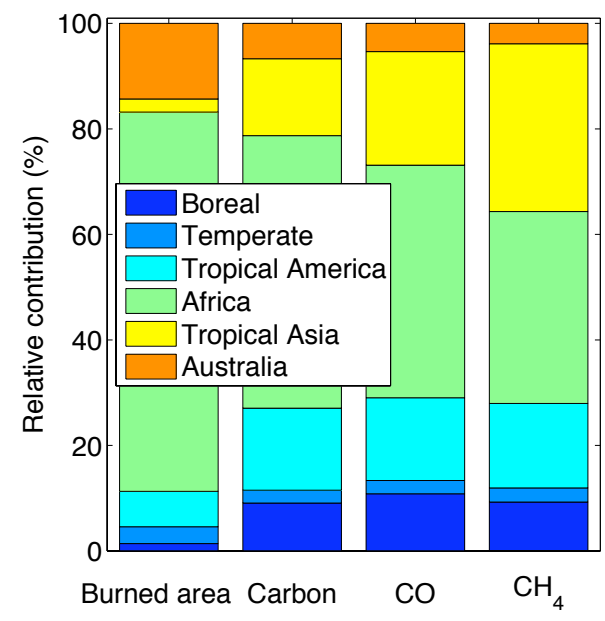

Fig. 10. Relative contribution (\%) from different regions to 19972009 average global total burned area and fire emissions of carbon, $\mathrm{CO}$, and $\mathrm{CH}_{4}$. The different regions were composed of BONA and BOAS (Boreal), TENA, EURO, CEAS (Temperate), CEAM, NHSA, and SHSA (Tropical America), MIDE, NHAF, and SHAF (Africa), SEAS and EQAS (Tropical Asia), and AUST for Australia.

dreae, personal communication, 2009) the role of savanna regions like Africa and Australia diminished while the role of forest and deforestation fires in areas with higher woody fuel loads increased (Fig. 10). This is because of more complete oxidation of fuels and thus reduced production of $\mathrm{CH}_{4}$, $\mathrm{CO}$ and other reduced trace gases in grass fires compared to fires in shrublands, forests, and peatlands. Africa, for example, accounted for $72 \%$ of global burned area, $52 \%$ of global carbon emissions, $44 \%$ of $\mathrm{CO}$ emissions and $36 \%$ of $\mathrm{CH}_{4}$ emissions (Fig. 10). On the other hand Southeast and Equatorial Asia accounted for only $2.5 \%$ of global burned area but due to higher fuel loads, including peats that emit more reduced trace gases per unit carbon combusted, these regions accounted for $22 \%$ of $\mathrm{CO}$ and $32 \%$ of $\mathrm{CH}_{4}$ emissions. Since the surface area of Equatorial Asia was much smaller than any of our other regions, the emissions density was highest in this region (Fig. 11).

\subsubsection{Partitioning between fire types}

Fires in grasslands and savannas were the largest contributor to global fire carbon emissions, accounting for on average $44 \%$ of total emissions during 2001-2009 (Figs. 12, 13). $23 \%$ of fire carbon emissions were net carbon emissions (likely not compensated for by regrowth) either due to tropical deforestation, degradation, or peat fires, most importantly in Southern Hemisphere South America (37\% of all deforestation fires) and Equatorial Asia (all tropical peat fires and $19 \%$ of all deforestation fires). Since the partitioning in the MODIS era was assumed to be the most reliable, we focused our analysis on the 2001-2009 period (Fig. 12, 


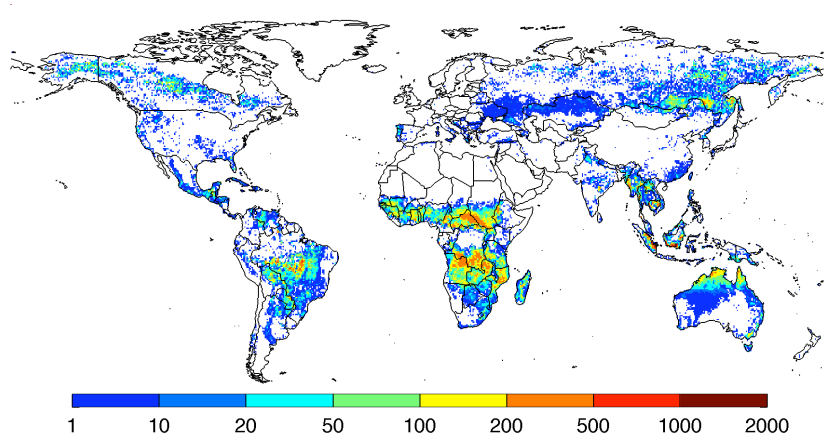

Fig. 11. Mean annual fire carbon emissions $\left(\mathrm{g} \mathrm{C} \mathrm{m}^{-2}\right.$ year $\left.^{-1}\right)$, averaged over 1997-2009. This quantity is the product of the fuel consumption (e.g., Fig. 6) and the burned area within the grid cell, divided by the total area of the grid cell.

Table S1). However, considering the full 1997-2009 period, the contribution of peat fires to total global emissions increased from $4 \%$ to $5 \%$ because of high peat fire emissions in 1997. The major regions contributing to net fire carbon emissions were Southern Hemisphere South America and Equatorial Asia. While deforestation emissions in Southern Hemisphere South America were substantially larger than those in Equatorial Asia, total net emissions in Equatorial Asia exceeded those in Southern Hemisphere South America because of the important role of peat burning.

Forest fires were a dominant contributor to emissions in the boreal regions (96\% in boreal North America and $81 \%$ in boreal Asia) while agricultural waste fires were important in Europe, the Middle East, and Central Asia. Almost all fires in Central Asia north of the Black, Caspian, and Aral Seas were in agricultural areas (Fig. 13). Since these agricultural fires may not leave a clear burned area signal in the $500 \mathrm{~m}$ data used here, our emissions estimates for these fires were likely conservative because we detected only a fraction of the actual agricultural fire activity. Part of this underestimate may be compensated for in our modeling approach because our framework did not explicitly include harvest, leading to an overestimation of fuel loads.

On a global scale, peat fire emissions were most variable from year to year as measured by the coefficient of variation (CV, standard deviation divided by the mean, Fig. 8). Their $\mathrm{CV}$ of 1.76 was about a factor 5 larger than the CV of deforestation and degradation, and forest fires (0.37 and 0.36 ). Agricultural waste burning and grassland and savanna fires were relatively constant on a global scale with coefficients of variation of 0.18 and 0.11 , respectively. Regionally, deforestation fires also were more variable, especially in Northern Hemisphere South America (CV of 1.37) and Equatorial Asia (1.10). The main deforestation region (Southern Hemisphere South America) had a CV of 0.64. Agricultural waste burning and grassland and savanna fires were not only relatively constant on a global scale; also regional variations were modest compared to other sources with the exception of Australia (CV of 0.29 for grassland and savanna fires).

\subsubsection{Uncertainties}

Results of the Monte Carlo simulation indicated that globally, uncertainties were around $20 \%(1 \sigma)$ for annual carbon estimates during the MODIS era (2001-2009) and somewhat higher during the years before when burned area was derived from ATSR and VIRS hot spots (Fig. 14). Regionally, uncertainties were highest in boreal regions and Equatorial Asia where organic soil burning occurs (Fig. S6). One factor that had a major impact on the spatial distribution of the uncertainties was whether mapped burned area was available, or whether burned area estimates were derived from fire hot spot - burned area relations. For the latter, uncertainties were much higher. This was not only the case in the pre-MODIS era, but also for about $10 \%$ of the total burned area in the MODIS era for which no burned area maps were available (Giglio et al., 2010). Because uncertainties were often higher than the absolute burned area and because negative burned area estimates were truncated at 0 , the mode of the Monte Carlo runs was higher than the estimates reported throughout the paper (Figs. 14, S6). The uncertainty analysis focused on carbon emissions, for trace gas emissions the added uncertainty of emissions factors should be taken into account (Andreae and Merlet, 2001).

\subsection{Fuel consumption}

Fuel consumption (reported here as $\mathrm{gC}$ per $\mathrm{m}^{2}$ of area burned) broadly followed biome distributions with low biomass density biomes such as grasslands and savannas burning less fuel than high biomass density types such as forests (Fig. 6). Fuel consumption in our model depended on biomass availability, tree mortality, and combustion completeness (Fig. S7). The relatively abrupt increase in fuel consumption when moving from savannas to woodlands and from woodlands to tropical forests was mostly caused by increases in tree mortality. In areas with low tree cover density the tree mortality was low (1\%) so fuels consisted mainly of litter and (dead) grass, while in tropical forest areas up to $100 \%$ of the biomass was susceptible to fire. In addition, the combustion completeness was increased in deforestation areas when fire persistence was high; this led to higher fuel consumption in the southern Amazon, for example, as compared with Africa. High fuel loads were also found in peatland areas in Indonesia, most notably the southern part of Borneo and northwestern Sumatra. Equatorial Asia had by far the highest mean fuel consumption (Table 4), because the majority of fires burned in peatlands and forested areas.

In grasslands and savannas, areas with lower fire return times, higher precipitation rates, or higher tree densities had higher levels of fuel consumption. High precipitation rates lead in general to more fuels, causing the gradient of fuel 

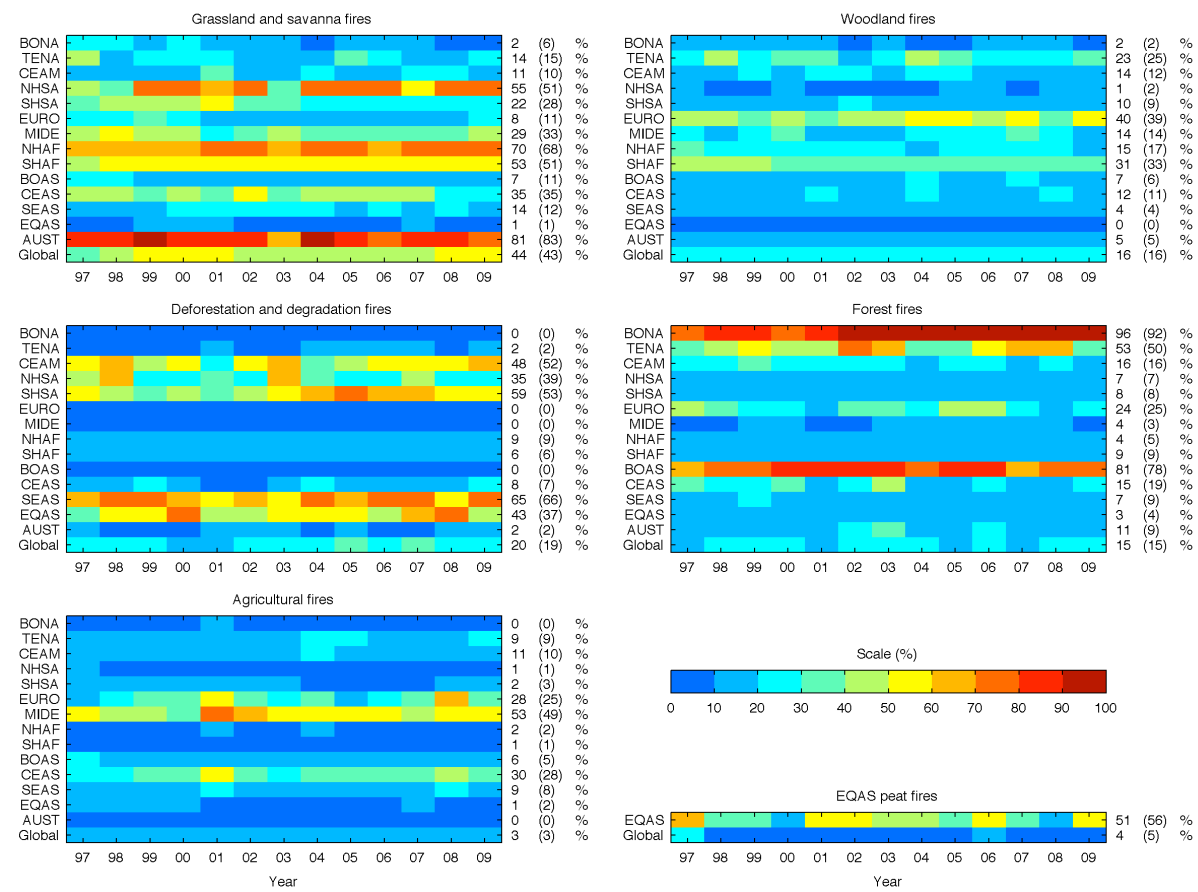

Fig. 12. Percent contribution of different fire types to annual fire emissions in each region. Absolute values are given in Table S1. Average percentages are given for the 2001-2009 MODIS period as well as for the full 1997-2009 time period (in parenthesis).

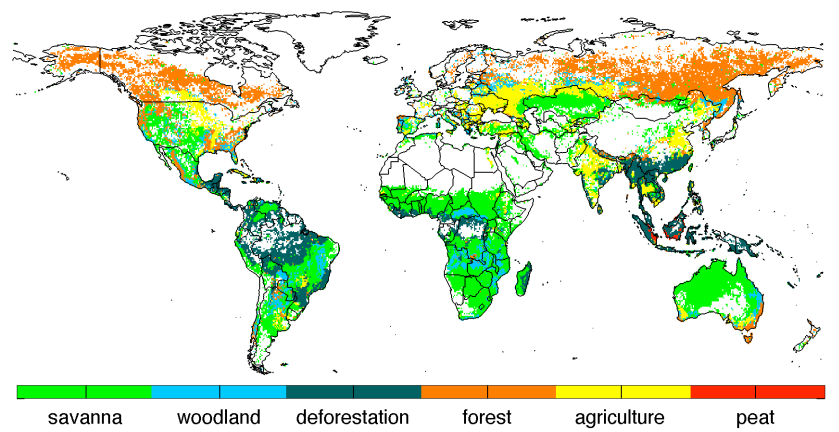

Fig. 13. Dominant fire type in each $0.5^{\circ}$ grid cell based on carbon emissions. Savanna fires include grassland fires; deforestation includes degradation. Woodland and savanna fires were separated based on the relative contributions from woody or herbaceous fuels to total emissions, respectively.

consumption observed in Africa and Australia (Fig. 6). There is evidence that since increased precipitation rates are often accompanied by increased tree cover density, the amount of grass available to burn decreases. In our model this was compensated for by an increase in fire-induced tree mortality. Savanna fires in South America had considerably higher levels of fuel consumption than those in Africa, which in turn consumed more carbon than most of the fires in Australia. Because in Southern Hemisphere Africa comparatively more fires were detected in woodlands than in

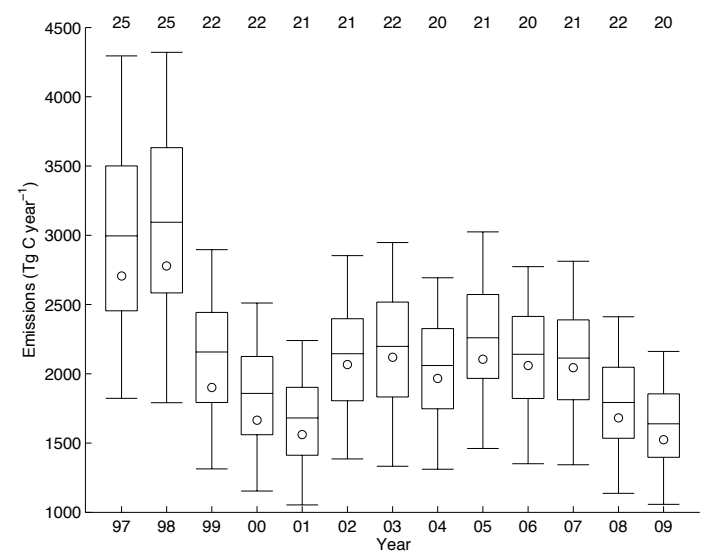

Fig. 14. Annual uncertainties expressed as the 5th, 25th, 50th, 75th, and 95th percentiles of 2000 runs from a set of Monte Carlo simulations. Circles denote the estimates reported throughout the paper, which do not necessarily align with the 50th percentiles due to truncation of several parameters in the Monte Carlo simulations. Numbers on the top of the plot indicate $1 \sigma$ uncertainties in annual fire emissions in percent of the median estimate from Monte Carlo simulations, assuming a Gaussian distribution. Note that uncertainties are larger on regional and monthly scales (Fig. S6).

Northern Hemisphere Africa, average fuel consumption here was higher $\left(448 \mathrm{~g} \mathrm{C} \mathrm{m}^{-2}\right.$ in Southern Hemisphere Africa vs. $377 \mathrm{~g} \mathrm{C} \mathrm{m}^{-2}$ in Northern Hemisphere Africa). Although fuel consumption was somewhat skewed (exacerbated by the 
log scale in Fig. 5), median fuel consumption was close to the mean; most fires in Northern Hemisphere Africa burned between 200 and $300 \mathrm{~g} \mathrm{C} \mathrm{m}^{-2}$, and between 300 and $400 \mathrm{~g} \mathrm{C} \mathrm{m}^{-2}$ in Southern Hemisphere Africa .

In boreal forests most fires burned between 2 and $5 \mathrm{~kg} \mathrm{C} \mathrm{m}^{-2}$ (Figs. 5 and 6). When considering all fires, average fuel consumption was $2662 \mathrm{~g} \mathrm{C} \mathrm{m}^{-2}$ in boreal North America and $1979 \mathrm{~g} \mathrm{C} \mathrm{m}^{-2}$ in boreal Asia (Table 4). Less than $10 \%$ of these fuels were from the burning of standing trees and leaves; most was related to burning of the duff layer and organic soils (Table 4). Average fuel consumption in boreal Asia was lower than in boreal North America because a larger fraction of burned area occurred in areas with lower fuel loads (e.g., in grasslands and agriculture (Figs. 5 and 6).

\section{Discussion}

\subsection{Source contributions}

\section{Deforestation, degradation, and peatland fires}

We found that on average, about a quarter of total carbon emissions from fire (or $0.5 \mathrm{PgC}_{\mathrm{Cear}}{ }^{-1}$ ) contributed to the build-up of atmospheric $\mathrm{CO}_{2}$ because they were likely not or only partly balanced by regrowth. This deforestation, degradation, and peatland component of global fire emissions was confined to the tropics (Figs. 13, S8). Roughly 3/5th of this stemmed from deforestation and degradation fires inside the humid tropical forest biome, $1 / 5^{\text {th }}$ from deforestation and degradation in the non-humid tropical forest biome, and the remaining $1 / 5^{\text {th }}$ from tropical peat burning (Table S1).

While crucial for interpreting the atmospheric $\mathrm{CO}_{2}$ signal, the uncertainty in this net carbon emissions estimate is large. There are reasons to believe that our estimates are conservative. First, the approach used to estimate deforestation rates captured about $80 \%$ of total deforestation rates reported by other studies. Whether the remaining $20 \%$ is due to deforestation or degradation not involving fires (e.g., logging) or whether our simple approach underestimated firedriven deforestation rates is unknown. Second, we focused on the tropical forest biome for deforestation. In addition, net emissions may occur in areas outside this biome. Hansen et al. (2010), for example, found higher rates of forest loss in boreal and temperate regions than in the tropical forest biome over 2000-2005. These may be partly compensated for by regrowth or forest thickening in other regions, but may also indicate net forest loss. In our analysis of the burned area time series, some of the woodland areas, especially in southern Africa, had fire return intervals that did not appear sustainable. This suggests our approach may have excluded some types of degradation fires because it is not trivial to separate these fires from those that are part of a natural cycle (or a sustainable human-driven fire regime). Case studies that investigate the fate of the burned areas at higher spatial reso- lution are likely to be more successful in understanding these dynamics over time. Multi-decadal moderate resolution time series of burned area are also crucial for detecting these types of changes in fire regimes.

Fire emissions estimates in deforestation regions have been used in the past to complement other approaches to calculate deforestation emissions, for example those based on reported deforestation rates, biomass density inventories, and deforestation biomass loss trajectories (e.g., Houghton et al., 2003). In the IPCC 4th Assessment, for example, deforestation emissions were estimated by doubling tropical fire emissions to account for emissions from other sources, including respiration of leftover plant materials and soil carbon following deforestation (Olivier et al., 2005). Following this approach and using the GFED3 time series described here, total deforestation estimates (including peat carbon emissions) would be $1 \mathrm{Pg} \mathrm{C}_{\text {year }}{ }^{-1}$, supporting earlier satellite-based deforestation estimates for the 1990s (DeFries et al., 2002; Achard et al., 2004). However, besides the substantial uncertainties in our deforestation fire emissions estimates, the doubling of the estimate to arrive at total deforestation carbon emissions is prone to large errors and more research is needed to lower uncertainties. One feature that is likely robust is the pattern of interannual variability, supporting for example the downward trend in deforestation emissions observed over the past few years in Brazil (e.g., Nepstad et al., 2009). One exception was found in the year 2007; while PRODES-reported deforestation rates were below average, fire emissions for Southern Hemisphere South America were higher than in any other year in our record (see also Gloudemans et al., 2009). While the exact causes for these differences remain unclear (e.g., Torres et al., 2010), precipitation rates may explain part of the variability (Aragão et al., 2008; Le Page et al., 2010). This precipitation-firedeforestation link is more pronounced in Equatorial Asia (Field et al., 2009; van der Werf et al., 2008), where emissions increased again in 2009 due to El Niño conditions after two very low fire years, but not to levels seen during earlier El Niño events in 1997, 2002, and 2006. Combining Southern Hemisphere South America and Equatorial Asia, emissions from these two important deforestation regions resulted in below-average deforestation fire emissions in the latter part of our record.

While the sum of deforestation, degradation, and peat fire emissions accounted for about a quarter of total carbon emissions, for $\mathrm{CH}_{4}$ these sources were key contributing to $44 \%$ of total $\mathrm{CH}_{4}$ emissions of $20 \mathrm{Tg} \mathrm{CH}_{4}$ year $^{-1}$. This was mostly due to the large $\mathrm{EF}$ for $\mathrm{CH}_{4}$ in peat areas, which was three times as high as the EF for tropical deforestation fires, and almost 10 times that of the EF for grassland and savanna fires. 


\section{Agricultural waste burning}

Our estimates of fires in agricultural areas, including emissions from leftover crop residues, are likely conservative for several reasons. First, most of these fires are small in comparison to the native 500 meter pixel resolution of the MODIS burned area time series we used, making change detection difficult. Second, these fires often follow harvest in many cropping systems, leading to a smaller drop in the vegetation index than what may occur in less managed ecosystems and again making it difficult to calculate burned area. Hence, we probably underestimate the area burned in agricultural waste burning areas. Fuel loads may compensate for part of this; since harvest is not explicitly included in the model (although the drop in $f$ APAR will translate into a transfer of biomass from leaves to litter) we will likely overestimate fuel loads. On average, we found emissions from this source

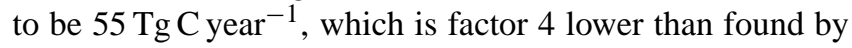
Yevich and Logan (2003). The spatial distribution of emissions closely resembles those found by Korontzi et al. (2006), which is not surprising because the datasets used are similar. Noteworthy is that Korontzi et al. (2006) found that between 8 and $11 \%$ of fire hot spots were observed in agricultural areas over 2001-2003; combining this with average emissions of $1.9 \mathrm{PgC}_{\text {year }}{ }^{-1}$ we found during these years results in a similar estimate as found by Yevich and Logan (2003) if we assume that each fire hot spot represents and equal amount of emissions. While hot spots integrate the effects of burned area and fuel consumption, they do not necessarily scale linearly with emissions (e.g., van der Werf et al., 2006). Nevertheless, this independent assessment provides one line of evidence that we need to develop new higher resolution approaches to estimate burned area in these areas.

\section{Savanna and woodland burning}

The largest source of global carbon emissions were fires in grasslands and savannas (44\%), and when combined with fires in woodlands, this set accounted for $60 \%$ of total global emissions. This is not surprising given the prominent role of savanna-dominated Africa and Australia in the global budget. Our distinction between grasslands and savannas on one hand, and woodlands on the other was somewhat arbitrary (based on whether herbaceous or woody fuels were the dominant source of emissions). In earlier studies (e.g., Crutzen and Andreae, 1990) this distinction was not made. The combined estimates of savanna, grassland, and woodland emissions from our analysis and Crutzen and Andreae (1990) agree to within 5\% (Fig. 15). The approaches used to derive these estimates, however, are fundamentally different. Crutzen and Andreae (1990) assumed that all savanna areas in the tropics burned with frequencies ranging from every year to every 4 years based on data from Menaut et al. (1991). They also assumed that mean fuel consumption

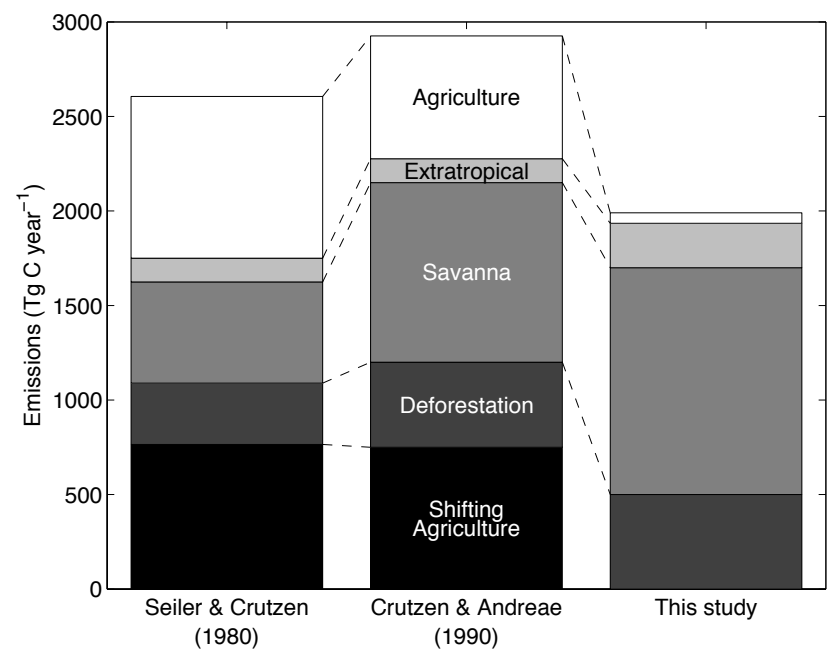

Fig. 15. Partitioning of total fire carbon emissions according to Seiler and Crutzen (1980), Crutzen and Andreae (1990), and this study. We used the extratropical assessment of Seiler and Crutzen (1980) to complete the tropical assessment of Crutzen and Andreae (1990). Note that we did not separate emissions from shifting agriculture from other types of deforestation in this study; our "deforestation" class therefore includes all fire types in tropical forest regions.

for these fires was $55 \mathrm{~g} \mathrm{C} \mathrm{m}^{-2}$, near the low end of many recent field estimates. In contrast, our burned area time series indicated that even the most frequently burning savanna areas (those receiving between 1000 and $1500 \mathrm{~mm}$ of rain annually), burned on average only once every 4 years during 2001-2009. Consequently, fuel consumption was higher in our study. In addition, we considered woodland burning. These two factors compensated for lower estimates of burned area in this study.

\section{Forest fires}

Although fuel loads were high in forests, globally the role of forest fires (excluding deforestation fires and woodland burning) was relatively modest; about $15 \%$ of total carbon emissions was due to the burning of forests. Our model did not separate ground from crown fires and thus fuel consumption in boreal North America and boreal Asia was relatively similar. There are indications though that the fire regime in boreal North America is more characterized by crown fires while ground fires are more prevalent in boreal Asia (Harden et al., 2000; Wooster and Zhang, 2004). Even though the aboveground fuel component is relatively small, not including these dynamics is an additional source of uncertainty.

\subsubsection{Comparison against GFED2}

Our revised estimate of carbon emissions from global fires was on average $13 \%$ lower than what we found previously 


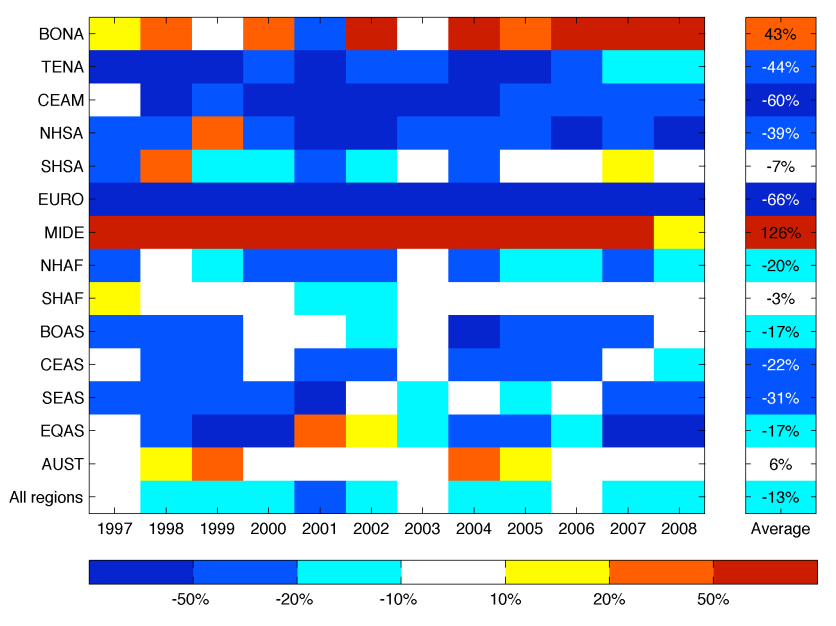

Fig. 16. Differences in fire carbon emissions estimates between GFED3 and GFED2, as a percent of GFED2 estimates. Positive numbers indicate GFED3 is higher than GFED2 and vice versa.

(van der Werf et al., 2006) for the 1997-2008 period (Fig. 16; GFED2 was not updated after 2008). The decrease in CO emissions also was $13 \%$ (Fig. S9), although in many regions the ratio of $\mathrm{C}$ to $\mathrm{CO}$ changed considerably between GFED2 and GFED3. Trace gas calculations based on the modeled carbon fluxes were impacted in two contrasting ways. First, in GFED2 we assumed a dry matter carbon content of $45 \%$ while mass balance equations based on the data in Table 5 from Andreae and Merlet (2001) indicate that $48 \%$ is more appropriate for most fire types. The calculated carbon emissions thus represent $6 \%$ less dry matter emissions to which emission factors were subsequently applied to derive trace gas fluxes. This had the effect of reducing trace gas emissions. However, here we included peat-specific emission factors for tropical peatland fires for $\mathrm{CO}$ and $\mathrm{CH}_{4}$, which were higher than those used previously when they were based on deforestation emission factors. In addition, the deforestation and degradation fires in the non-humid tropical forest biome as well as woodland fires received higher emission factors than in GFED2. These two types of adjustments more or less compensated each other on a global scale.

Regionally, differences were larger than the global comparison suggests, but interannual variability was relatively similar in both versions. The only regions where emissions increased substantially were boreal North America (+43\%) and the Middle East (including the Sahara, $+126 \%$ ). This was mostly due to increases in burned area (11 and 90\% respectively) and, for boreal North America, higher levels of fuel consumption $(+39 \%)$. The higher fuel consumption in boreal North America was primarily the result of 1) an increase in the fraction of area burned in forest, and 2) the inclusion of soil burning in the herbaceous fraction of grid cells occurring in forested regions. Specifically, tree cover density is relatively low in the forests of boreal North America and previously we assumed that fires burning in the herbaceous fraction of these forests were grassland fires that only burned aboveground fuels. It is, however, more realistic to assume that this herbaceous fraction is due to larger distances between trees (i.e., more open taiga areas) and that the fires also consume the soil organic matter in the areas between trees.

All areas dominated by grassland and savanna fires had a decrease in fire emissions due to the modifications we made to better represent senescence of herbaceous fuels and thus the turnover times of herbaceous leaves. The decrease in emissions in Southern Hemisphere Africa was small (-3\%), mostly because lower average fuel consumption $(-41 \%)$ was partly compensated for by a $38 \%$ increase in burned area. Burned area also increased in Northern Hemisphere Africa (20\% more burned area) and Australia (6\% more burned area), but not enough to offset the decrease in fuel consumption. The $22 \%$ decrease in emissions in Central Asia was caused primarily by lower fuels; burned area did not change substantially here.

Other areas that experienced a reduction in estimates of fire carbon emissions included temperate North America and Central America, as well as Northern Hemisphere South America. These decreases in emissions were mostly caused by lower levels of burned area and in the case of temperate North America also a reduction in fuel consumption. Burned area also decreased significantly in Europe leading to a $66 \%$ reduction in carbon emissions. The decreases in Southeast $(-31 \%)$ and Equatorial Asia $(-17 \%)$ also were largely due to reduced levels of burned area, that was partly compensated for by higher levels of fuel consumption in Equatorial Asia. Including peat-specific emission factors resulted in an increase in CO emissions in Equatorial Asia (9\%).

Because of the large range in fuel consumption, changes in burned area do not necessarily translate directly into changes in emissions; it depends where those changes occur. Our current model was for a large part driven by mapped 500 meter burned area (in the MODIS era, where more than $90 \%$ of the total burned area was mapped directly) while in GFED2 the model depended solely on a regression tree relationship between fire hot spots and burned area. The improved burned area led to higher quality predictions that better matched observations across the continental US, Canada, and Alaska (Giglio et al., 2010). Together with the other improvements described above (summarized in Table 3 ) we believe that several important sources of uncertainty were substantially reduced in GFED3.

\subsubsection{Comparison against other bottom-up estimates}

Few global estimates of fire emissions exist that employ new burned area datasets; most assessments were based on pilot burned area studies for the year 2000; GBA2000 (Gregoire et al., 2003) and GLOBSCAR (Simon et al., 2004). These burned area estimates have been used in different ways 
to estimate emissions. Hoelzemann et al. (2004) coupled GLOBSCAR burned area (and ATSR fire hot spots in burned area data gaps) with biomass density estimates from the Lund-Potsdam-Jena (LPJ) dynamic global vegetation model (DGVM) to estimate total emissions of $1.7 \mathrm{Pg} \mathrm{C}_{\text {year }}{ }^{-1}$ in the year 2000. For the same year and using the GBA2000 burned area dataset, Ito and Penner (2004) estimated emissions from open fires of $1.4 \mathrm{Pg} \mathrm{C}_{\text {year }}{ }^{-1}$ combining satellitederived vegetation information and literature-based values of combustion completeness and relations between vegetation types and fuel loads, most at the native $(1 \mathrm{~km})$ burned area resolution. Earlier versions of our modeling work estimated emissions in 2000 of $2.7 \mathrm{Pg} \mathrm{C}_{\text {year }}{ }^{-1}$ (GFED1, van der Werf et al., 2004) and $2.0 \mathrm{Pg} \mathrm{C}_{\text {year }}{ }^{-1}$ (GFED2, van der Werf et al., 2006).

The substantial differences between these studies was due in part to differences in burned area data; Jain et al. (2007) employed three different burned area datasets in their Integrated Science Assessment Model (ISAM) to find that $\mathrm{CO}$ emissions ranged between 320 and $390 \mathrm{Tg} \mathrm{CO}$ year $^{-1}$ with much larger regional differences than the range of global burned area estimates would suggest. These CO estimates are substantially lower than earlier inventory methods; Galanter et al. (2000), for example, estimated CO emissions from savanna and forest burning of $554 \mathrm{Tg} \mathrm{CO}$ year $^{-1}$. Estimates for the year 2000, however, are probably not representative for mean annual emissions because emissions from several important fire areas (including tropical Asia and America) were below average (van der Werf et al., 2004). Globally, our results now indicate that emissions for the year 2000 were $1.7 \mathrm{Pg} \mathrm{C}_{\text {year }}{ }^{-1}$ while the average for 1997-2009 was $2.0 \mathrm{PgC}$ year $^{-1}$. When taking the full uncertainty range into account, our estimates still overlap with those mentioned above with the exception of van der Werf et al. (2004), which produced substantially higher estimates. Interannual variability, however, is still comparable to the results from van der Werf et al. (2004) supporting the conclusion that fires in Indonesia, Central and South America, and the boreal region contributed substantially to the high $\mathrm{CO}_{2}$ and $\mathrm{CH}_{4}$ growth rates during the 1997-1998 El Niño.

Much progress recently has been achieved in estimating emissions at regional scales. Lehsten et al. (2009) estimated fire emissions for 2001-2005 from Africa based on L3JRC burned area data (Tansey et al., 2008) and the SPITFIRE fire model embedded in the LPJ-Guess DGVM. They estimated that over this time period on average $195 \times 10^{4} \mathrm{~km}^{2}$ year $^{-1}$ burned, emitting $723 \pm 70 \mathrm{Tg} \mathrm{C}$ year $^{-1}$. We found that over the same time period $247 \times 10^{4} \mathrm{~km}^{2}$ year ${ }^{-1}$ burned which emitted on average $1031 \mathrm{TgC} \mathrm{year}^{-1}$. Average fuel consumption for the continent was thus comparable in these approaches, $417 \mathrm{~g} \mathrm{C} \mathrm{m}^{-2}$ year $^{-1}$ (this study) vs. $371 \mathrm{~g} \mathrm{C} \mathrm{m}^{-2}$ year $^{-1}$ (Lehsten et al., 2009), although the spatial distribution of burned area varied substantially.

Besides Africa, the boreal region and Australia may be the most intensively studied fire regions. Several authors have estimated emissions for the boreal region, with large differences partly related to the complex fuel composition where belowground fuels may comprise the largest fraction of the fuels (e.g., Amiro et al. 2001; DeGroot et al., 2007). Both our previous work and the emission estimates presented here fall in the range of previous emissions estimates (Kasischke et al., 2005; Soja et al., 2004) but uncertainties will remain large because several parameters (most importantly the depth of burning into organic soil) remain difficult to validate. Our emissions estimates for North America (including Mexico) are substantially lower then those from Wiedinmyer et al. (2006), especially for the US.

While both inventory and satellite-based estimates described above use the product of burned area, fuel loads, and combustion completeness to calculate emissions (Seiler and Crutzen, 1980), studies using satellite-measured fire radiative power (FRP) do not require these input datasets each with substantial uncertainty- but directly integrate FRP to total fire radiative energy (FRE), which is in turn related to total emissions (Wooster et al., 2002). Roberts and Wooster (2007) used geostationary Spinning Enhanced Visible and Infrared Imager (SEVIRI) active fire observations and calculated emissions for southern Africa for JulyOctober 2004 of 259-339 Tg dry matter (DM) burned, or $127-166 \mathrm{Tg} C$ assuming a DM carbon content of $48 \%$. For the same region and time period, GFED2 emissions were $387 \mathrm{Tg} \mathrm{C}$ while GFED3 estimates were $404 \mathrm{Tg}$ C. FRE-based estimates using MODIS observations are also substantially lower than our estimates: Ellicott et al. (2009) estimated DM emissions averaged over 2001-2007 for all of Africa were $716 \mathrm{Tg} \mathrm{DM}_{\text {year }}{ }^{-1}\left(351 \mathrm{Tg} \mathrm{C}_{\text {year }}{ }^{-1}\right.$ ) and $305 \mathrm{Tg} \mathrm{DM}$ year $^{-1}$ for South America $\left(149 \mathrm{Tg} \mathrm{C}_{\text {year }}{ }^{-1}\right)$. For Africa, GFED2 estimates were $1175 \mathrm{Tg}$ C year while GFED3 estimates were $1018 \mathrm{Tg} \mathrm{C}_{\text {year }}{ }^{-1}$, exceeding those of Ellicott et al. (2009) by factors of 3.3 and 2.9, respectively. The difference was somewhat smaller for South America; while Ellicott et al. (2009) estimated emissions of $149 \mathrm{Tg} \mathrm{C}$ year $^{-1}$, the GFED2 based estimate was $373 \mathrm{Tg} \mathrm{C}_{\text {year }}{ }^{-1}$ (2.5 times higher) and GFED3 estimates $334 \mathrm{Tg} \mathrm{C}$ year $^{-1}$ (2.2 times higher). Thus, there remains a large discrepancy between biogeochemical model estimates combining burned area and fuel consumption and FRE/FRP approaches, with the latter having a factor of 2-3 lower emissions.

\subsubsection{Comparison against regional top-down assessments}

Since trace gas and aerosol emissions from fires are transported into the atmosphere, and many of these gases are measured by satellite, atmospheric measurements may be used to validate bottom-up estimates if the transport and chemical pathways are modeled correctly. If this approach is used, emission factors translating carbon or dry matter emissions to trace gas or aerosol emissions are required. Since these emission factors are sometimes poorly known and since their 
spatial and temporal variability is rarely taken into account, care should be taken translating findings of top-down assessments directly to carbon or dry matter emissions, although these shortcomings are probably less important for the study of interannual variability (e.g. Gloudemans et al., 2009).

Pfister et al. (2005) estimated that $30 \pm 5 \mathrm{Tg} \mathrm{CO}$ was emitted from fires in Alaska and Canada between June and August 2004, which was significantly higher than estimates based on GFED2 (16 Tg CO) but in line with our new results $(30 \mathrm{Tg} \mathrm{CO})$, mostly due to somewhat higher burned area and higher $\mathrm{CO}$ emission factors. Turquety et al. (2007) found comparable emissions. Another regional assessment employing satellite-based $\mathrm{CO}$ focused on Indonesia and surrounding countries between 2000 and 2006 and indicated that GFED2 overestimated emissions from Sumatra but that emissions from Borneo matched reasonably well with the distribution of CO columns observed in the atmosphere (van der Werf et al., 2008). In this area, carbon emissions in GFED3 are somewhat lower than those in GFED2 for 20012006 but due to the inclusion of specific peat emission factors, the $\mathrm{CO}$ emissions are somewhat higher GFED3 for Borneo, and lower for Sumatra. In Borneo, however, GFED3 indicates that 2002 and 2006 emission peaks were of similar magnitude while several atmospheric indicators $(\mathrm{CO}$, aerosols) indicate that 2006 was higher (Logan et al., 2008; Tosca et al., 2010).

Focusing on Africa, Chevallier et al. (2009) used MOPITT and the LMDZ-INCA chemistry transport model to estimate emissions with GFED2 $\mathrm{CO}$ emissions as a-priori input for 2000-2006. While Northern Hemisphere African CO concentrations appeared in agreement with those seen from MOPITT, those from the Southern Hemisphere were found to be too low, on average by $26 \%$. GFED3 CO emissions are 5\% higher in Southern Hemisphere Africa than GFED2 and likely more in agreement with the results from Chevallier et al. (2009), but the $22 \%$ decrease in Northern Hemisphere Africa will likely reduce the agreement between modeled and observed CO fluxes.

In short, we expect that overall the newly calculated emissions lead to better predictions of atmospheric trace gas and aerosol burdens. However, improvements in some regions will be accompanied by deterioration in other regions, similarly to the situation when we replaced version 1 with version 2 (Stavrakou et al., 2009).

\subsection{Uncertainties}

By combining new burned area with improved biogeochemical modeling to better model fuel loads we have attempted to reduce uncertainties in global fire emissions estimates. However, our estimates are still uncertain to at least $\sim 20 \%(1 \sigma)$ on global, annual scales for carbon emissions (Fig. 14), and higher for trace gas and aerosol emissions or when smaller regions or shorter time windows are considered. In addition, the uncertainties in the pre-MODIS era were up to
$25 \%$ higher. Several factors contribute to these uncertainties, which are described further below.

\subsubsection{Burned area}

Global-scale moderate resolution burned area maps as used here have improved over the last few years and compare favorably against high-resolution case studies in temperate and boreal forest regions, as well as in savanna regions in southern Africa (Giglio et al., 2009, 2010). In wooded savannas, burned area may be somewhat underestimated (Roy et al. 2009) while burned or cleared area in deforestation regions has not undergone a formal validation. Other uncertainties arise from the native resolution of the burned area product, in our case $500 \mathrm{~m}$. Here we have assumed that these grid cells burn completely when flagged as burned. In reality, however, this is often not the case. Early season burns, for example, are patchier than late season fires in Australia (e.g., Russell-Smith and Edwards, 2006). The patchiness may lead to an error in burned area estimates. Overestimation of area burned may occur as a consequence of including unburned patches within pixels classified as burned. On the other hand, underestimation of area burned may occur in pixels where only a small fraction of the area burned, leaving little signal for the burned area algorithm to operate on. Errors may also be expected from fires in tropical forest areas where persistent cloud cover obscures the surface (Roy et al., 2008). By combining burned area with fire persistence, we have made the first attempt to distinguish deforestation fires from other types of fires in this biome, and at the same time increase burned area estimates here to better capture reported cleared or deforested areas.

\subsubsection{Fuel loads}

Although uncertainty in burned area datasets is still substantial and the highest quality datasets still do not capture all burned area (Roy et al., 2009), some are of substantially higher quality than earlier attempts to characterize burned area around the world indicating that fuel loads, combustion completeness, and emission factors are now becoming the most uncertain components of emissions estimates at a global scale (Hoelzemann et al., 2004). This ordering has existed on regional scales for many years where higher resolution (e.g., Landsat) data has been available (French et al., 2004). Our model captured biomass density estimates in the Amazon (Saatchi et al., 2007), fuel build-up in savanna regions of Africa (Savadogo et al., 2007) and Australia (Williams et al., 1998), and estimated fuel consumption in boreal America in agreement with field measurements and higher spatial resolution studies, see Sects. 2.2-2.4. However, discrepancies remained and variability in reported fuel consumption is large. Part of the reason may be related to scale; measurements are often made on small plots and are less frequently extrapolated over the area within a fire perimeter. 
This scaling is crucial for making realistic comparisons with global-scale models, especially in heterogeneous landscapes that may include a range of ecosystem types, fuel loads and burn severities.

Savanna and grassland fuel loads in GFED2 may have been too high (Roberts et al., 2008; Ellicott et al., 2009). By improving the scalar that determines the transfer of leaves to litter our modeled fuel loads are now lower than in previous work and are in better agreement with measurements from several field studies. Fuel loads are still higher than observed in some areas though; the mode of fuel consumption in Africa was $300-400 \mathrm{~g} \mathrm{C}$ per $\mathrm{m}^{2}$ burned while most field studies indicate fuel consumption is around $200 \mathrm{~g} \mathrm{C}^{\text {per }} \mathrm{m}^{2}$ burned or even lower. The model, however, does a reasonable job in simulating fuel build-up over the first few years after a fire. The model bias may have several causes. First, field campaigns may focus on frequently burning regions that have little time to accumulate fuels. For example, it is often stated that most savannas burn every year or every other year. Our burned area data, however, indicated that only $14 \%$ of the landscape exposed to fire in Africa burned annually. For Australia, fire return times were mostly between 5 and 10 years, and $2 \%$ of the total area burned annually. Second, if fires burn preferentially in a certain part of the grid cell then our approach will overestimate fuel loads. For example, if we find that on average $50 \%$ of a grid cell burns we assume the whole grid cell has a fire return time of 2 years and each year $50 \%$ of the whole grid cell is burned. Another possibility though is that $50 \%$ of the grid cell burns annually and the other $50 \%$ does not burn. In the latter case emissions are lower than in the former because fuel loads are smaller. If this is the case, our approach could overestimate emissions by $\sim 30 \%$. In reality the error is smaller because its magnitude decreases with increasing fire return time. We also expect to have reduced these errors moving from GFED2 to GFED3 by increasing the spatial resolution by a factor 4 . Finally, fuel consumption in Africa showed substantial spatial variability, with increasing values towards the equator. For southern Africa, most measurements were made in the more arid and less productive areas (e.g., South Africa, Zambia) while satellite data indicates that areas further north (Angola, D.R. Congo) see more fire activity. Since parts of these areas are woodlands, they boost the average fuel consumption estimates.

\subsubsection{Combustion completeness and emission factors}

Both combustion completeness and emission factors vary to a large extent based on geographical and meteorological conditions as well as fuel composition (e.g. Kortontzi et al., 2003; Shea et al., 1996; Andreae and Merlet, 2001). While our combustion completeness values as well as depth of burning in peatlands and organic soils were scaled based on soil moisture conditions, this should be seen as a simple approach to incorporate spatial and regional variability; more work is needed to better represent this variability. While a relatively large body of research providing ground measurements of emission factors is available, understanding the variability of these emission factors for large-scale research applications is challenging (Van Leeuwen and van der Werf, 2010). Improving the representation of depth of burning into peat and organic soil may also be difficult because of limited availability of observations and concurrent meteorology, although new approaches hold considerable promise (Ballhorn et al., 2009; Boby et al., 2010). Validating combustion completeness is problematic as well; in grassland and savanna areas the errors may be small because fine fuels are almost always observed to burn completely. In deforestation regions, however, the variability is large due to differences in land management and post-fire land use that will be difficult to model and validate with the currently available information.

\subsection{Future developments}

Several of the uncertainties in our estimates are related to landscape heterogeneity within our $0.5^{\circ}$ modeling grid. Although we have made a distinction between deforestation fires, peat fires, fires occurring in the herbaceous parts of the grid cell, and fires occurring in the wooded parts of the grid cells, our approach is a first attempt and other key parameters (e.g., $f$ APAR) are still taken as the average of the $0.5^{\circ}$ grid cell thus ignoring this sub grid scale variability. In addition, we cannot distinguish the fire history within a grid cell; if for example a grid cell burns for $50 \%$ on average each year it makes a substantial difference whether $50 \%$ of the area burns every year or whether the whole grid cell burns every two years.

Modeling at higher spatial resolution may partly overcome some of these issues. Ideally, fire emissions results would be based on the native resolution of important datasets (burned area, $f$ APAR) that are available at 500 meter resolution. This appears to be feasible from a technical point of view. An added benefit is that this would allow for better validation with local measurements. Geo-location issues, especially when combining input datasets from different platforms (Hyer et al., 2009), and realistically extrapolating other input datasets (e.g., climate data) to the finer resolution are important issues that have to be addressed.

Besides improving spatial resolution and the quality of input datasets, there is a clear need to better understand the partitioning of combusted biomass into trace gases. While a large number of emission factor measurements used for this partitioning have revealed the broad-scale differences in emission factors between biomes (Andreae and Merlet, 2001; Janhäll et al., 2009), a clear description of spatial and temporal variability in emission factors is challenging with currently available information (Van Leeuwen and van der Werf, 2010). Multi-species satellite measurements or continuous tower measurements in important biomass burning regions are needed to better understand the rules governing the 
partitioning, including seasonal and environmental controls on reduced gas production.

\section{Conclusions}

We have updated our Global Fire Emissions Database (GFED, now version 3) using improved satellite input data and made several modifications to our modeling framework. These modifications include explicitly accounting for deforestation and forest degradation fires in the model, partitioning fire emissions into different source categories, and adding an uncertainty analysis. The main findings can be summarized as follows:

- Global fire emissions averaged over 1997-2009 were 2.0 $\mathrm{Pg} \mathrm{C}_{\text {year }}{ }^{-1}$ according to our modeling framework with important contributions from Africa (52\%), South America (15\%), Equatorial Asia (10\%), the boreal region (9\%), and Australia (7\%).

- The largest contributor to global fire carbon emissions were fires in grasslands and savannas (44\%), with another $16 \%$ emitted from woodland fires. Forest fires, mostly confined to temperate and boreal regions accounted for $15 \%$. We estimated that about $23 \%$ of fire carbon emissions stemmed from tropical deforestation, degradation, and fires burning in tropical peatland areas. These fire emissions of approximately $0.5 \mathrm{PgC}$ year $^{-1}$ were probably a net source of $\mathrm{CO}_{2}$ to the atmosphere because they may not be compensated for by regrowth. This estimate does not include carbon fluxes from decomposition of remaining plant material following deforestation fires, and is confined to the tropics. Agricultural areas contributed about $3 \%$ of the global total carbon emissions from fires, but this estimate was likely conservative. These numbers represent averages during 2001-2009 when MODIS burned area observations were available; the role of peat burning increased somewhat when considering the 1997-2000 period due to high emissions in 1997 and 1998 in Indonesia.

- Emissions were highest in 1998 (2.8 $\left.\mathrm{Pg} \mathrm{C}_{\text {year }}{ }^{-1}\right)$ with almost all fire regions experiencing above normal fire activity, followed by 1997 (2.7 $\mathrm{Pg} \mathrm{C}_{\text {year }}{ }^{-1}$ ) mostly due to emissions from Indonesia. The years 2000, 2001, 2008, and 2009 had lower amounts of fire activity with mean emissions of $\sim 1.6 \mathrm{PgC} \mathrm{year}^{-1}$. From 2002 to 2007 , fire emissions were relatively constant around $2.1 \mathrm{PgC}$ year $^{-1}$. Within this period, positive anomalies in some regions cancelled negative anomalies, most notably in 2006 and 2007 when fire emissions in South America were low and high, respectively, while fire emissions in Equatorial Asia showed the reverse pattern. The global decrease in fire emissions observed during 2008 and 2009 was partly due to decreasing deforestation and tropical forest degradation fires.
- While Africa was by far the largest source of fire $\mathrm{CO}_{2}$ emissions, emissions of reduced trace gases like $\mathrm{CO}$ and $\mathrm{CH}_{4}$ in tropical America and tropical Asia were almost as high due to a larger share of deforestation and peat fires emitting higher amounts of reduced trace gases per unit biomass combusted. Deforestation, degradation, and tropical peat fires contributed to almost half of global fire emissions of $\mathrm{CH}_{4}$.

- Emissions estimates were more reliable than our previous attempts to characterize global fire emissions, but uncertainties remained and were on the order of at least $20 \%(1 \sigma)$ for global, annual carbon sums. Uncertainties were higher in the boreal region as well as in Equatorial Asia due to difficulties in estimating fuel consumption in organic soils. In addition, deforestation-fire carbon emissions were uncertain primarily due to uncertainties in cleared or burned area estimates and secondarily from challenges in estimating fuel loads and combustion completeness. Since the burned area assessments used here may underestimate the amount of burned area in wooded savanna and agricultural areas, and our approach to model deforestation fires may also underestimate cleared areas, our estimates are likely conservative.

- Future fire emissions estimates could take better advantage of native resolution burned area and $f$ APAR estimates, which would enable a better representation of heterogeneity in the landscape and enable more useful comparisons with ground measurements. Due to lack of spatially-explicit input datasets necessary to estimate fuel loads, difficulties in estimating depth of burning in boreal and tropical peat areas, and unreliable burned area estimates in deforestation areas, it is unlikely that in the near future uncertainties will be reduced to levels comparable to those associated with fossil fuel emissions.

Gridded $0.5^{\circ} \times 0.5^{\circ}$ monthly burned area, emissions estimates, partitioning into different sources, the $\mathrm{C} 4$ fraction of $\mathrm{CO}_{2}$ emissions, and biospheric fluxes (NPP and $\mathrm{R}_{h}$ ) were provided to the scientific community for large-scale research as GFED3 through http://www.globalfiredata.org and will be updated frequently.

\section{Supplement related to this article is available online at: http://www.atmos-chem-phys.net/10/11707/2010/ acp-10-11707-2010-supplement.pdf.}

Acknowledgements. This research was supported by the EU Seventh Research Framework Programme (MACC project, contract number 218793), and NASA grants NNX08AF64G, NNX08AE97A, and NNX08AL03G.

Edited by: J. Rinne 


\section{References}

Achard, F., Eva, H. D., Mayaux, P., Stibig, H. J., and Belward, A.: Improved estimates of net carbon emissions from land cover change in the tropics for the 1990s, Global Biogeochem. Cy., 18, GB2008, doi:10.1029/2003GB002142, 2004.

Amiro, B. D., Todd, J. B., Wotton, B. M , Logan, K. A., Flannigan, M. D., Stocks, B. J., Mason, J. A., Martell, D. L., and Hirsch, K. G.: Direct carbon emissions from Canadian forest fires, 19591999, Can. J. Forest Res., 31, 512-525, 2001.

Andreae, M. O., and Merlet, P.: Emission of trace gases and aerosols from biomass burning, Glob. Biogeochem. Cy., 15, 955966, 2001

Aragao, L. E. O. C., Malhi, Y., Barbier, N., Lima, A., Shimabukuro, Y., Anderson, L., and Saatchi, S.: Interactions between rainfall, deforestation and fires during recent years in the Brazilian Amazonia, Philos. T. R. Soc. B, 363, 1779-1785, doi:10.1098/rstb.2007.0026, 2008.

Arino, O., Rosaz, J. M., and Poloup, P.: The ATSR World Fire Atlas and a Synergy with POLDER Aerosol Products, Proceedings of the International Workshop on the Applications of the ERS Along Track Scanning Radiometer, 8, 1999.

Arora, V. K. and Boer, G. J.: Fire as an interactive component of dynamic vegetation models, J. Geophys. Res.-Biogeo, 110, G02008, doi:10.1029/2005JG000042, 2005.

Ballhorn, U., Siegert, F., Mason, M., and Limin, S.: Derivation of burn scar depths and estimation of carbon emissions with LIDAR in Indonesian peatlands, P. Natl. Acad. Sci. USA, 106, 2121321218, doi:10.1073/pnas.0906457106, 2009.

Batjes, N. H.: Total carbon and nitrogen in the soils of the world, Eur. J. Soil Sci., 47, 151-163, 1996.

Boby, L. A., Schuur, E. A. G., Mack, M. C., Verbyla, D., and Johnstone, J. F.: Quantifying fire severity, carbon, and nitrogen emissions in Alaska's boreal forest, Ecol. Appl., 20(6), 1633-1647, doi:10.1890/08-2295.1, 2010.

Bowman, D. M. J. S., Balch, J. K., Artaxo, P., Bond, W. J., Carlson, J. M., Cochrane, M. A., D’Antonio, C. M., DeFries, R. S., Doyle, J. C., Harrison, S. P., Johnston, F. H., Keeley, J. E., Krawchuk, M. A., Kull, C. A., Marston, J. B., Moritz, M. A., Prentice, I. C., Roos, C. I., Scott, A. C., Swetnam, T. W., van der Werf, G. R., and Pyne, S. J.: Fire in the Earth System, Science, 324, 481-484, doi:10.1126/science.1163886, 2009.

Chang, D., and Song, Y.: Estimates of biomass burning emissions in tropical Asia based on satellite-derived data, Atmos. Chem. Phys., 10, 2335-2351, doi:10.5194/acp-10-2335-2010, 2010.

Chevallier, F., Fortems, A., Bousquet, P., Pison, I., Szopa, S., Devaux, M., and Hauglustaine, D. A.: African CO emissions between years 2000 and 2006 as estimated from MOPITT observations, Biogeosciences, 6, 103-111, doi:10.5194/acp-6-103-2009, 2009.

Chuvieco, E., Giglio, L., \& Justice, C.O.: Global characterization of fire activity: toward defining fire regimes from Earth observation data. Global Change Biol., 14, 1488-1502, doi:10.1111/j.13652486.2008.01585.x, 2008.

Christian, T. J., Kleiss, B., Yokelson, R. J., Holzinger, R., Crutzen, P. J., Hao, W. M., Saharjo, B. H., and Ward, D. E.: Comprehensive laboratory measurements of biomass-burning emissions: 1 . Emissions from Indonesian, African, and other fuels, J. Geophys. Res.-Atmos, 108, 4719, doi:10.1029/2003JD003704, 2003.

Cramer, W. P. and Leemans, R.: Global 30-Year Mean Monthly Cli- matology, 1930-1960, V[ersion]. 2.1. Data set, available online at: http://www.daac.ornl.gov, from Oak Ridge National Laboratory Distributed Active Archive Center, Oak Ridge, Tennessee, USA, doi:10.3334/ORNLDAAC/416, 2001.

Crutzen, P. J. and Andreae, M. O: Biomass burning in the tropics: Impact on atmospheric chemistry and biogeochemical cycles, Science, 250, 1669-1678, 1990.

de Groot, W. J., Landry, R., Kurz, W. A., Anderson, K. R., Englefield, P., Fraser, R. H., Hall, R. J., Banfield, E., Raymond, D. A., Decker, V., Lynham, T. J., and Pritchard, J. M.: Estimating direct carbon emissions from Canadian wildland fires 1, Int. J. Wildland Fire, 16, 593-606, doi:10.1071/WF06150, 2007.

de Groot, W. J., Pritchard, J. M., and Lynham, T. J.: Forest floor fuel consumption and carbon emissions in Canadian boreal forest fires, Can. J. Forest Res., 39, 367-382, doi:10.1139/X08-192, 2009.

DeFries, R. S., Houghton, R. A., Hansen, M. C., Field, C. B., Skole, D., and Townshend, J.: Carbon emissions from tropical deforestation and regrowth based on satellite observations for the 1980s and 1990s, P. Natl. Acad. Sci. USA, 99, 14256-14261, doi:10.1073/pnas.182560099, 2002.

Defries, R. S., Morton, D. C., van der Werf, G. R., Giglio, L., Collatz, G. J., Randerson, J. T., Houghton, R. A., Kasibhatla, P. K., and Shimabukuro, Y.: Fire-related carbon emissions from land use transitions in southern Amazonia, Geophys. Res. Lett., 35, L22705, doi:10.1029/2008GL035689, 2008.

Duncan, B. N., Martin, R. V., Staudt, A. C., Yevich, R., and Logan, J. A.: Interannual and seasonal variability of biomass burning emissions constrained by satellite observations, J. Geophys. Res.-Atmos, 108, 4100, doi:10.1029/2002JD002378, 2003.

Ellicott, E., Vermote, E., Giglio, L., and Roberts, G.: Estimating biomass consumed from fire using MODIS FRE, Geophys. Res. Lett., 36, 1-5, doi:10.1029/2009GL038581, 2009.

Fearnside, P. M.: Deforestation in Brazilian Amazonia: History, rates, and consequences, Conserv. Biol., 19, 680-688, 2005.

Field, C. B., Randerson, J. T., and Malmstrom, C. M.: Global net primary production - combining ecology and remote sensins, Remote. Sens. Environ, 51, 74-88, 1995.

Field, R. D., van der Werf, G. R., and Shen, S. S. P.: Human amplification of drought-induced biomass burning in Indonesia since 1960, Natl. Geosci., 2, 185-188, doi:10.1038/NGEO443, 2009.

French, N. H. F., Goovaerts, P., and Kasischke, E. S.: Uncertainty in estimating carbon emissions from boreal forest fires, J. Geophys. Res.-Atmos, 109, D14S08, doi:10.1029/2003JD003635, 2004.

Friedl, M. A., McIver, D. K., Hodges, J. C. F., Zhang, X. Y., Muchoney, D., Strahler, A. H., Woodcock, C. E., Gopal, S., Schneider, A., Cooper, A., Baccini, A., Gao, F., and Schaaf, C.: Global land cover mapping from MODIS: algorithms and early results, Remote Sens. Environ., 83, 287-302, 2002.

Galanter, M., Levy, H., and Carmichael, G. R.: Impacts of biomass burning on tropospheric $\mathrm{CO}, \mathrm{NO}_{\mathrm{x}}$, and $\mathrm{O}_{3}$, J. Geophys. Res.Atmos., 105, 6633-6653, 2000.

Giglio, L., Descloitres, J., Justice, C. O., and Kaufman, Y. J.: An enhanced contextual fire detection algorithm for MODIS, Remote. Sens. Environ., 87, 273-282, doi:10.1016/S00344257(03)00184-6, 2003a.

Giglio, L., Kendall, J. D., and Mack, R.: A multi-year active fire dataset for the tropics derived from the TRMM VIRS, Int. J. Remote Sens., 24, 4505-4525, 
doi:10.1080/0143116031000070283, 2003b.

Giglio, L., van der Werf, G. R., Randerson, J. T., Collatz, G. J., and Kasibhatla, P. S.: Global estimation of burned area using MODIS active fire observations, Atmos. Chem. Phys., 6, 957974, doi:10.5194/acp-6-957-2006, 2006.

Giglio, L., Loboda, T., Roy, D. P., Quayle, B., and Justice, C. O.: An active-fire based burned area mapping algorithm for the MODIS sensor, Remote. Sens. Environ., 113, 408-420, doi:10.1016/j.rse.2008.10.006, 2009.

Giglio, L., Randerson, J. T., van der Werf, G. R., Kasibhatla, P. S., Collatz, G. J., Morton, D. C., and DeFries, R. S.: Assessing variability and long-term trends in burned area by merging multiple satellite fire products, Biogeosciences, 7, 1171-1186, doi:10.5194/bg-7-1171-2010, 2010.

Gloudemans, A. M. S., de Laat, A. T. J., Schrijver, H., Aben, I., Meirink, J. F., and van der Werf, G. R.: SCIAMACHY CO over land and oceans: 2003-2007 interannual variability, Atmos. Chem. Phys, 9, 3799-3813, doi:10.5194/acp-9-3799-2002009.

Gregoire, J. M., Tansey, K., and Silva, J. M. N.: The GBA2000 initiative: developing a global burnt area database from SPOTVEGETATION imagery, Int. J. Remote. Sens., 24, 1369-1376, doi:10.1080/0143116021000044850, 2003.

Guild, L. S., Kauffman, J. B., Ellingson, L. J., Cummings, D. L., and Castro, E. A.: Dynamics associated with total aboveground biomass, C, nutrient pools, and biomass burning of primary forest and pasture in Rondonia, Brazil during SCAR-B, J. Geophys. Res.-Atmos, 103, 32091-32100, 1998.

Hansen, M. C., DeFries, R. S., Townshend, J. R. G., Carroll, M., Dimiceli, C., and Sohlberg, R. A.: Global Percent Tree Cover at a Spatial Resolution of 500 Meters: First Results of the MODIS Vegetation Continuous Fields Algorithm, Earth Interact., 7(10), 1-15, 2003.

Hansen, M. C., Stehman, S. V., Potapov, P. V., Loveland, T. R., Townshend, J. R. G., DeFries, R. S., Pittman, K. W., Arunarwati, B., Stolle, F., Steininger, M. K., Carroll, M., and DiMiceli, C.: Humid tropical forest clearing from 2000 to 2005 quantified by using multitemporal and multiresolution remotely sensed data, P. Natl. Acad. Sci. USA, 105, 9439-9444, doi:10.1073/pnas.0804042105, 2008.

Hansen, M. C., Stehman, S. V., and Potapov, P. V.: Quantification of global gross forest cover loss, P. Natl. Acad. Sci. USA, 107, 8650-8655, doi:10.1073/pnas.0912668107, 2010.

Hao, W. M., Ward, D. E., Olbu, G., and Baker, S. P.: Emissions of $\mathrm{CO}_{2}, \mathrm{CO}$, and hydrocarbons from fires in diverse African savanna ecosystems, J. Geophys. Res.-Atmos., 101, 23577-23584, 1996.

Harden, J., Trumbore, S. E., Stocks, B., Hirsch, A., Gower, S. T., O'Neill, K. P., and Kasischke, E. S.: The role of fire in the boreal carbon budget, Glob. Change Biol., 6(S1), 174-184, doi:10.1046/j.1365-2486.2000.06019.x, 2000.

Hely, C., Caylor, K. K., Dowty, P., Alleaume, S., Swap, R. J., Shugart, H. H., and Justice, C. O.: A temporally explicit production efficiency model for fuel load allocation in southern Africa, Ecosystems, 10, 1116-1132, doi:10.1007/s10021-007-9082-3, 2007.

Hoelzemann, J. J., Schultz, M. G., Brasseur, G. P., Granier, C., and Simon, M.: Global Wildland Fire Emission Model (GWEM): Evaluating the use of global area burnt satellite data, J. Geophys. Res.-Atmos., 109, D14S04, doi:10.1029/2003JD003666, 2004.
Houghton, R. A.: Revised estimates of the annual net flux of carbon to the atmosphere from changes in land use and land management 1850-2000, Tellus B, 55, 378-390, 2003.

Huffman, G. J., Adler, R. F., Morrissey, M., Bolvin, D. T., Curtis, S., Joyce, R., McGavock, B., Susskind, J.: Global Precipitation at One-Degree Daily Resolution from Multi-Satellite Observations. J. Hydrometeorol., 2, 36-50, 2001.

Hui, D. F. and Jackson, R. B.: Geographical and interannual variability in biomass partitioning in grassland ecosystems: a synthesis of field data, New Phytologist, 169, 85-93, doi:10.1111/j.1469-8137.2005.01569.x, 2006.

Hyer, E. J. and Reid, J. S.: Baseline uncertainties in biomass burning emission models resulting from spatial error in satellite active fire location data, Geophys. Res. Lett., 36, L05802, doi:10.1029/2008GL036767, 2009.

Ito, A. and Penner, J. E.: Global estimates of biomass burning emissions based on satellite imagery for the year 2000, J. Geophys. Res.-Atmos., 109, D14S05, doi:10.1029/2003JD004423, 2004.

Jain, A. K.: Global estimation of CO emissions using three sets of satellite data for burned area, Atmos. Environ., 41, 6931-6940, doi:10.1016/j.atmosenv.2006.10.021, 2007.

Jain, A. K., Tao, Z. N., Yang, X. J., and Gillespie, C.: Estimates of global biomass burning emissions for reactive greenhouse gases (CO, NMHCs, and $\mathrm{NO}_{\mathrm{x}}$ ) and $\mathrm{CO} 2$, J. Geophys. Res.-Atmos., 111, D06304, doi:10.1029/2005JD006237, 2006.

Janhäll, S., Andreae, M. O., and Pöschl, U.: Biomass burning aerosol emissions from vegetation fires: particle number and mass emission factors and size distributions, Atmos. Chem. Phys., 10, 1427-1439, doi:10.5194/acp-10-1427-2010, 2010.

Kasischke, E. S., Christensen, N., and Stocks, B. J.: Fire, global warming, and the carbon balance of boreal forests, Ecol. Appl., 5, 437-451, 1995 .

Kasischke, E. S., Hyer, E. J., Novelli, P. C., Bruhwiler, L. P., French, N. H. F., Sukhinin, A. I., Hewson, J. H., and Stocks, B. J.: Influences of boreal fire emissions on northern hemisphere atmospheric carbon and carbon monoxide, Glob. Biogeochem. Cy., 19, GB1012, doi:10.1029/2004GB002300, 2005.

Kauffman, J. B., Cummings, D. L., Ward, D. E., and Babbitt, R.: Fire in the Brazilian Amazon 1: Biomass, nutrient pools. And losses in slashed primary forests, Oecologia, 104, 397-408, 1995.

Kloster, S., Mahowald, N. M., Randerson, J. T., Thornton, P. E., Hoffman, F. M., Levis, S., Lawrence, P. J., Feddema, J. J., Oleson, K. W., and Lawrence, D. M.: Fire dynamics during the 20th century simulated by the Community Land Model, Biogeosciences, 7, 1877-1902, doi:10.5194/bg-7-1877-2010, 2010.

Korontzi, S., Ward, D. E., Susott, R. A., Yokelson, R. J., Justice, C. O., Hobbs, P. V., Smithwick, E. A. H., and Hao, W. M.: Seasonal variation and ecosystem dependence of emission factors for selected trace gases and PM2.5 for southern African savanna fires, J. Geophys. Res.-Atmos., 108, 4758, doi:10.1029/2003JD003730, 2003.

Korontzi, S., McCarty, J., Loboda, T., Kumar, S., and Justice, C.: Global distribution of agricultural fires in croplands from 3 years of Moderate Resolution Imaging Spectroradiometer (MODIS) data, Glob. Biogeochem. Cy., 20, GB2021, doi:10.1029/2005GB002529, 2006.

Langenfelds, R., Francey, R., Pak, B., and Steele, L.: Interannual growth rate variations of atmospheric $\mathrm{CO}_{2}$ and its $\delta^{13} \mathrm{C}, \mathrm{H}_{2}$, 
$\mathrm{CH}_{4}$, and $\mathrm{CO}$ between 1992 and 1999 linked to biomass burning, Global Biogeochem. Cy., 2002.

Langmann, B., Duncan, B., Textor, C., Trentmann, J., and van der Werf, G. R.: Vegetation fire emissions and their impact on air pollution and climate, Atmos. Environ., 43, 107-116, doi:10.1016/j.atmosenv.2008.09.047, 2009.

Le Page, Y., Pereira, J. M. C., Trigo, R., da Camara, C., Oom, D., and Mota, B.: Global fire activity patterns (1996-2006) and climatic influence: an analysis using the World Fire Atlas, Atmos. Chem. Phys., 8, 1911-1924, doi:10.5194/acp-8-1911-2008, 2008.

Le Page, Y., van der Werf, G. R., Morton, D. C., and Pereira, J. M. C.: Modeling fire-driven deforestation potential in Amazonia under current and projected climate conditions, J. Geophys. Res.-biogeosciences, 115, G03012, doi:10.1029/2009JG001190, 2010.

Lehsten, V., Tansey, K., Balzter, H., Thonicke, K., Spessa, A., Weber, U., Smith, B., and Arneth, A.: Estimating carbon emissions from African wildfires, Biogeosciences, 6, 349-360, doi:10.5194/bg-6-349-2009, 2009.

Logan, J., Megretskaia, I., Nassar, R., and Murray, L.: Effects of the 2006 El Niño on tropospheric composition as revealed by data from the Tropospheric Emission Spectrometer (TES), Geophys. Res. Lett., doi:10.1029/2007GL031698, 2008.

Marlon, J. R., Bartlein, P. J., Carcaillet, C., Gavin, D. G., Harrison, S. P., Higuera, P. E., Joos, F., Power, M. J., and Prentice, I. C.: Climate and human influences on global biomass burning over the past two millennia, Nat. Geosci., 1, 697-702, doi:10.1038/ngeo313, 2008.

McNaughton, S. J., Oesterheld, M., Frank, D. A., and Williams, K. J.: Ecosystem-level patterns of primary productivity and herbivory in terrestrial habitats, Nature, 341, 142-144, 1989.

Mieville, A., Granier, C., Liousse, C., Guillaume, B., Mouillot, F., Lamarque, J.-F., Gregoire, J.-M., and Petron, G.: Emissions of gases and particles from biomass burning during the 20th century using satellite data and an historical reconstruction, Atmos Environ, 44, 1469-1477, doi:10.1016/j.atmosenv.2010.01.011, 2010.

Mollicone, D., Eva, H. D., and Achard, F.: Human role in Russian wild fires, Nature, 440, 436-437, doi:10.1038/440436a, 2006.

Morton, D. C., Defries, R. S., Randerson, J. T., Giglio, L., Schroeder, W., and van der Werf, G. R.: Agricultural intensification increases deforestation fire activity in Amazonia, Global Change Biol., 14, 2262-2275, doi:10.1111/j.13652486.2008.01652.x, 2008.

Mouillot, F., Narasimha, A., Balkanski, Y., Lamarque, J. F., and Field, C. B.: Global carbon emissions from biomass burning in the 20th century, Geophys. Res. Lett., 33, L01801, doi:10.1029/2005GL024707, 2006.

Myneni, R. B., Hoffman, S., Knyazikhin, Y., Privette, J. L., Glassy, J., Tian, Y., Wang, Y., Song, X., Zhang, Y., Smith, G., Lotsch, A., Friedl, M., Morisette, J. T., Votava, P., Nemani, R. R., and Running, S. W.: Global products of vegetation leaf area and fraction absorbed PAR from year one of MODIS data, Remote Sens. Environ., 83, 214-231, 2002.

Nepstad, D., Soares, B. S., Merry F., Lima, A., Moutinho, P., Carter, J., Bowman, M., Cattaneo, A., Rodrigues, H., Schwartzman, S., McGrath, D. G., Stickler, C. M., Lubowski, R., Piris-Cabezas, P., Rivero, S., Alencar, A., Almeida, O., Stella, O.: The end of deforestation in the Brazilian Amazon, Science, 326, 5958, doi:10.1126/science, 2009.

Olson, D. M., Dinerstein, E., Wikramanayake, E. D., 2001, Burgess, N. D., Powell, G. V. N., Underwood, E. C., D’Amico, J. A., Itoua, I., Strand, H. E., Morrison, J. C., Loucks, C. J. , Allnutt, T. F., Ricketts, T. H., Kura, Y., Lamoreux, J. F., Wettengel, W. W., Heda, P., and Kassem, K. R.: Terrestrial ecoregions of the world a new map of life on earth, Bioscience, 51, 933-938, 2001.

Page, S. E., Siegert, F., Rieley, J. O., Boehm, H. d. v., Jaya, A., and Limin, S.: The amount of carbon released from peat and forest fires in Indonesia during 1997, Nature, 420, 61-65, doi:10.1038/nature01131, 2002.

Pfister, G., Hess, P. G., Emmons, L. K., Lamarque, J. F., Wiedinmyer, C., Edwards, D. P., Petron, G., Gille, J. C., and Sachse, G. W.: Quantifying CO emissions from the 2004 Alaskan wildfires using MOPITT CO data, Geophys. Res. Lett., 32, L11809, doi:10.1029/2005GL022995, 2005.

Plummer, S., Arino, O., Simon, M., and Steffen, W.: Establishing an earth observation product service for the terrestrial carbon community: the GLOBCARBON initiative, Mitigation and Adaptation Strategies for Global Change, 11, 97-111, 2006.

Potter, C. S., Randerson, J. T., Field, C. B., Matson, P. A., Vitousek, P. M., Mooney, H. A., and Klooster, S. A.: Terrestrial ecosystem production - a process model based on global satellite and surface data, Glob. Biogeochem. Cy., 7, 811-841, 1993.

Pyne, S. J.: Fire in America: A Cultural History of Wildland and Rural Fire, Princeton University Press, NJ, USA, 1982.

Randerson, J. T., Thompson, M. V., Malmstrom, C. M., Field, C. B., and Fung, I. Y.: Substrate limitations for heterotrophs: Implications for models that estimate the seasonal cycle of atmospheric $\mathrm{CO}_{2}$, Glob. Biogeochem. Cy., 10, 585-602, 1996.

Randerson, J. T., van der Werf, G. R., Collatz, G. J., Giglio, L., Still, C. J., Kasibhatla, P. S., Miller, J. B., White, J. B., DeFries, R. S., and Kasischke, E. S.: Fire emissions from C3 and $\mathrm{C} 4$ vegetation and their influence on interannual variability of atmospheric $\mathrm{CO}_{2}$ and $\delta 13 \mathrm{CO} 2$, Global Biogeochem. Cy., 19, GB2019, doi:10.1029/2004GB002366, 2005.

Randerson, J. T., Liu, H., Flanner, M. G., Chambers, S. D., Jin, Y., Hess, P. G., Pfister, G., Mack, M. C., Treseder, K. K., Welp, L. R., Chapin, F. S., Harden, J. W., Goulden, M. L., Lyons, E., Neff, J. C., Schuur, E. A. G., and Zender, C. S.: The impact of boreal forest fire on climate warming, Science, 314, 1130-1132, doi:10.1126/science.1132075, 2006.

Roberts, G. J. and Wooster, M. J.: Fire detection and fire characterization over Africa using Meteosat SEVIRI, IEEE Trans. Geosci. Remote Sens., 46, 1200-1218, doi:10.1109/TGRS.2008.915751, 2008.

Roy, D. P. and Boschetti, L.: Southern Africa Validation of the MODIS, L3JRC, and GlobCarbon Burned-Area Products, IEEE Trans. Geosci. Remote Sens., 47, 1032-1044, doi:10.1109/TGRS.2008.2009000, 2009.

Roy, D. P., Boschetti, L., Justice, C. O., and Ju, J.: The collection 5 MODIS burned area product - Global evaluation by comparison with the MODIS active fire product, Remote Sens. Environ., 112, 3690-3707, doi:10.1016/j.rse.2008.05.013, 2008.

Russell-Smith, J. and Edwards, A. C.: Seasonality and fire severity in savanna landscapes of monsoonal Northern Australia, Int. J. Wildland Fire, 15, 541-550, doi:10.1071/WF05111, 2006.

Saatchi, S. S., Houghton, R. A., Alvala, R. C. D. S., Soares, J. V., and Yu, Y.: Distribution of aboveground live biomass 
in the Amazon basin, Global Change Biol., 13, 816-837, doi:10.1111/j.1365-2486.2007.01323.x, 2007.

Savadogo, P., Zida, D., Sawadogo, L., Tiveau, D., Tigabu, M., and Oden, P. C.: Fuel and fire characteristics in savanna-woodland of West Africa in relation to grazing and dominant grass type, Int. J. Wildland Fire, 16, 531-539, doi:10.1071/WF07011, 2007.

Schultz, M. G.: On the use of ATSR fire count data to estimate the seasonal and interannual variability of vegetation fire emissions, Atmos. Chem. Phys., 2, 387-395, doi:10.5194/acp-2-387-2002, 2002.

Schultz, M. G., Heil, A., Hoelzemann, J. J., Spessa, A., Thonicke, K., Goldammer, J. G., Held, A. C., Pereira, J. M. C., and van het Bolscher, M.: Global wildland fire emissions from 1960 to 2000, Glob. Biogeochem. Cy., 22, GB2002, doi:10.1029/2007GB003031, 2008.

Seiler, W. and Crutzen, P. J.: Estimates of gross and net fluxes of carbon between the biosphere and atmosphere from biomass burning, Clim. Change, 2, 207-247, 1980.

Shea, R., Shea, B., Kauffman, J., Ward, D., and Haskins C.: Fuel biomass and combustion factors associated with fires in savanna ecosystems of South Africa and Zambia, J. Geophys. Res., 101(D19), 23551-23568, doi:10.1029/95JD02047, 1996.

Simon, M., Plummer, S., Fierens, F., Hoelzemann, J. J., and Arino, O.: Burnt area detection at global scale using ATSR-2: The GLOBSCAR products and their qualification, J. Geophys. Res.Atmos., 109, D14S02, doi:10.1029/2003JD003622, 2004.

Soja, A. J., Cofer, W. R., Shugart, H. H., Sukhinin, A. I., Stackhouse, P. W., McRae, D. J., and Conard, S. G.: Estimating fire emissions and disparities in boreal Siberia (1998-2002), J. Geophys. Res.-Atmos., 109, D14S06, doi:10.1029/2004JD004570, 2004.

Stavrakou, T., Muller, J.-F., De Smedt, I., Van Roozendael, M., van der Werf, G. R., Giglio, L., and Guenther, A.: Evaluating the performance of pyrogenic and biogenic emission inventories against one decade of space-based formaldehyde columns, Atmos. Chem. Phys., 9, 1037-1060, doi:10.5194/acp-9-1037-2009, 2009.

Tansey, K., Gregoire, J.-M., Defourny, P., Leigh, R., Pekel, J.-F., van Bogaert, E., and Bartholome, E.: A new, global, multiannual (2000-2007) burnt area product at $1 \mathrm{~km}$ resolution, Geophys. Res. Lett., 35, L01401, doi:10.1029/2007GL031567, 2008.

ter Steege, H., Pitman, N. C. A., Phillips, O. L., Chave, J., Sabatier, D., Duque, A., Molino, J.-F., Prevost, M.F., Spichiger, R., Castellanos, H., von Hildebrand, P., and Vasquez, R.: Continental-scale patterns of canopy tree composition and function across Amazonia, Nature, 443, 444-447, doi:10.1038/nature05134, 2006.

Thonicke, K., Venevsky, S., Sitch, S., and Cramer, W.: The role of fire disturbance for global vegetation dynamics: coupling fire into a Dynamic Global Vegetation Model, Global Ecol. Biogeogr., 10, 661-677, 2001.

Torres, O., Chen, Z., Jethva, H., Ahn, C., Freitas, S. R., and Bhartia, P. K.: OMI and MODIS observations of the anomalous 20082009 Southern Hemisphere biomass burning seasons, Atmos. Chem. Phys., 10, 3505-3513, doi:10.5194/acp-10-3505-2010, 2010.

Tosca, M. G., Randerson, J. T., Zender, C. S., Flanner, M. G., and Rasch, P. J.: Do biomass burning aerosols intensify drought in Equatorial Asia during El Nino?, Atmos. Chem. Phys., 10, 3515-
3528, doi:10.5194/acp-10-3515-2010, 2010.

Tucker, C. J., Pinzon, J. E., Brown, M. E., Slayback, D. A., Pak, E. W., and Mahoney, R.: An extended AVHRR 8-km NDVI data set compatible with MODIS and SPOT vegetation NDVI data, Int. J. Remote Sens., 26, 4485-4498, 2005.

Turquety, S., Logan, J. A., Jacob, D. J., Hudman, R. C., Leung, F. Y., Heald, C. L., Yantosca, R. M., Wu, S., Emmons, L. K., Edwards, D. P., and Sachse, G. W.: Inventory of boreal fire emissions for North America in 2004: Importance of peat burning and pyroconvective injection, J. Geophys. Res.-Atmos., 112, D12S03, doi:10.1029/2006JD007281, 2007.

van der Werf, G. R., Randerson, J. T., Collatz, G. J., and Giglio, L.: Carbon emissions from fires in tropical and subtropical ecosystems, Global Change Biol., 9, 547-562, 2003.

van der Werf, G. R., Randerson, J. T., Giglio, L., Collatz, G. J., Kasibhatla, P. S., and Arellano, A. F.: Interannual variability in global biomass burning emissions from 1997 to 2004, Atmos. Chem. Phys., 6, 3423-3441, doi:10.5194/acp-6-3523-2006, 2006.

van der Werf, G. R., Dempewolf, J., Trigg, S. N., Randerson, J. T., Kasibhatla, P. S., Giglio, L., Murdiyarso, D., Peters, W., Morton, D. C., Collatz, G. J., Dolman, A. J., and Defries, R. S.: Climate regulation of fire emissions and deforestation in Equatorial Asia, P. Natl. Acad. Sci. USA, 105, 20350-20355, doi:10.1073/pnas.0803375105, 2008a.

van der Werf, G. R., Randerson, J. T., Giglio, L., Gobron, N., and Dolman, A. J.: Climate controls on the variability of fires in the tropics and subtropics, Global Biogeochem. Cy., 22, GB3028, doi:10.1029/2007GB003122, 2008b.

van der Werf, G. R., Morton, D. C., Defries, R. S., Giglio, L., Randerson, J. T., Collatz, G. J., and Kasibhatla, P. S.: Estimates of fire emissions from an active deforestation region in the southern Amazon based on satellite data and biogeochemical modelling, Biogeosciences, 6, 235-249, doi:10.5194/bg-5-235-2009, 2009.

van Leeuwen, T. T. and van der Werf, G. R.: Spatial and temporal variability in the ratio of trace gases emitted from biomass burning, Atmos. Chem. Phys. Discuss., 10, 2355923599, doi:10.5194/acpd-10-23559-2010, 2010.

Walker, R., DeFries, R. S., del Carmen Vera-Diaz, M., Shimabukuro, Y., Venturieri, A.: The Expansion of Intensive Agriculture and Ranching in Brazilian Amazonia, in: Amazonia and Global Change, edited by: Keller, M., Bustamante, M., Gasj, J., and Silva Dias, P., American Geophysical Union, Geophysical Monograph Series 186, Washington DC, 61-81, 2009

Ward, D., Hao, W., Susott, R., Babbitt, R., and Shea, R.: Effect of fuel composition on combustion efficiency and emission factors for African savanna ecosystems, J. Geophys. Res., 101(D19), 23569-23576, doi:10.1029/95JD02595, 1996.

Westerling, A. L., Hidalgo, H. G., Cayan, D. R., and Swetnam, T. W.: Warming and earlier spring increase western US forest wildfire activity, Science, 313, 940-943, doi:10.1126/science.1128834, 2006.

Wiedinmyer, C., Quayle, B., Geron, C., Belote, A., McKenzie, D., Zhang, X., O’Neill, S., and Wynne, K. K.: Estimating emissions from fires in North America for air quality modeling, Atmos. Environ., 40, 3419-3432, doi:10.1016/j.atmosenv.2006.02.010, 2006.

Williams, R. J., Gill, A. M., and Moore, P. H. R.: Seasonal changes in fire behaviour in a tropical Savanna in Northern Australia, Int. 
J. Wildland Fire, 8, 227-239, 1998.

Wooster, M. J.: Small-scale experimental testing of fire radiative energy for quantifying mass combusted in natural vegetation fires, Geophys. Res. Lett., 29, 2027, doi:10.1029/2002GL015487, 2002.

Wooster, M. J. and Zhang, Y. H.: Boreal forest fires burn less intensely in Russia than in North America. Geophys. Res. Lett., 31, L20505, doi:10.1029/2004GL020805O, 2004.

Yevich, R. and Logan, J. A.: An assessment of biofuel use and burning of agricultural waste in the developing world, Glob. Biogeochem. Cy., 17, 1095, doi:10.1029/2002GB001952, 2003.

Yokelson, R. J., Susott, R., Ward, D. E., Reardon, J., and Griffith, D. W. T.: Emissions from smoldering combustion of biomass measured by open-path Fourier transform infrared spectroscopy, J. Geophys. Res.-Atmos., 102, 18865-18877, 1997.
Zhang, Y., Fu, R., Yu, H., Dickinson, R. E., Juarez, R. N., Chin, M., and Wang, H.: A regional climate model study of how biomass burning aerosol impacts land-atmosphere interactions over the Amazon, J. Geophys. Res., 113, D14S15, doi:10.1029/2007JD009449, 2008.

Zhang, Y.-C., Rossow, W. B., Lacis, A. A., Oinas, V., and Mishchenko, M. I.: Calculation of radiative fluxes from the surface to top of atmosphere based on ISCCP and other global data sets: Refinements of the radiative transfer model and the input data. J. Geophys. Res., 109, D19105, doi:10.1029/2003JD004457, 2004. 